Haruka Hirayama, Takuya Akiyama*, Satoshi Kimura, Deded S. Nawawi, Wasrin Syafii, Tomoya Yokoyama and Yuji Matsumoto

\title{
Influence of the $p$-hydroxyphenyl/guaiacyl ratio on the biphenyl and $\beta-5$ contents in compression wood lignins
}

https://doi.org/10.1515/hf-2019-0012

Received January 17, 2019; accepted April 2, 2019; previously published online May 24, 2019

\begin{abstract}
Reaction woods of three softwoods, Pinus merkusii, Cryptomeria japonica and Cedrus deodara, were investigated by alkaline nitrobenzene oxidation (NBO) to characterize the condensed-type structures in compression wood lignins. A novel biphenyl-type NBO product carrying guaiacyl (G)- and $p$-hydroxyphenyl (H)-units, dehydrovanillin- $p$-hydroxybenzaldehyde (HG-biphenyl product), was identified using the authentic standard compound. On the basis of the yield of this novel NBO product, as well as those of GG-biphenyl-, $\beta-5-$, and uncondensed-type products [e.g. dehydrodivanillin, 5-formylvanillin, vanillin and $p$-hydroxybenzaldehyde], the compression wood lignins contained more HG-type biphenyl and H-type $\beta$-5 structures than the opposite wood lignins. The increase in the condensed-type structure content was largely offset by the decreases in the content of GG-biphenyl and G-type $\beta-5$ structures. Consequently, the relative yields of biphenyl, $\beta-5$ and uncondensed-type NBO products were very similar between the compression wood and the opposite wood, even though the $\mathrm{H}$-unit having no methoxy group on its aromatic ring can be assumed to have a greater
\end{abstract}

\footnotetext{
*Corresponding author: Takuya Akiyama, Department of Forest Resource Chemistry, Forestry and Forest Products Research Institute, 1 Matsunosato, Tsukuba, Ibaraki 305-8687, Japan, e-mail: akiyamatakuya@affrc.go.jp

Haruka Hirayama, Tomoya Yokoyama and Yuji Matsumoto: Department of Biomaterial Sciences, Graduate School of Agricultural and Life Sciences, The University of Tokyo, Yayoi 1-1-1, Bunkyo-ku, Tokyo 113-8657, Japan

Satoshi Kimura: Department of Biomaterial Sciences, Graduate School of Agricultural and Life Sciences, The University of Tokyo, Yayoi 1-1-1, Bunkyo-ku, Tokyo 113-8657, Japan; and Department of Plant and Environmental New Resources, College of Life Sciences, Kyung Hee University, 1732 Deogyeong-daero, Giheung-ku, Yongin-si, Gyeonggi-do 446-701, Republic of Korea Deded S. Nawawi and Wasrin Syafii: Department of Forest Products, Faculty of Forestry, Bogor Agricultural University (IPB), Kampus IPB, Darmaga, Bogor 16680, Indonesia
}

probability to form condensed-type structures during lignin biosynthesis than the G-unit.

Keywords: 5-5 linkage, alkaline nitrobenzene oxidation, gymnosperm, methoxy group, noncondensed-type, reaction wood, phenylcoumaran, uncondensed-type

\section{Introduction}

Lignin, one of the three major cell wall components, provides the mechanical support allowing plants to stand upright. Lignin is a polymeric material composed of three phenylpropanoid units, $p$-hydroxyphenyl $(\mathrm{H})$, guaiacyl (G) and syringyl (S) units, which are derived from three traditional monolignols, $p$-coumaryl, coniferyl and sinapyl alcohol, respectively. Softwoods contain lignins that are primarily composed of G-units accompanied by a smaller proportion of H-units. Hardwood lignins additionally contain S-units. The proportion of $\mathrm{H} / \mathrm{G} / \mathrm{S}$ units is variable and closely related to the lignin content of the wood, the composition of the different lignin interunit linkages, and the stereochemical structures of $\beta-0-4$ structures (Akiyama et al. 2005; Yeh et al. 2006; Nawawi et al. 2016, 2017a,b). Although significant investigation into the effect of the $S / G$ ratio on the interunit linkage compositions of lignins has been carried out (Karhunen et al. 1995; Ralph et al. 2006; Stewart et al. 2009; Kishimoto et al. 2010; Hirayama et al. 2019), the influence of the $H / G$ ratio on the chemical structures in lignin remains unclear (Saito and Fukushima 2005; Ralph et al. 2006; Wagner et al. 2007; Weng et al. 2010).

The lignin content tends to be higher in softwoods (woody gymnosperm) than in hardwoods (woody angiosperm). The lignin content of hardwoods tends to be higher in species having lignin with a lower $\mathrm{S} / \mathrm{G}$ ratio (Akiyama et al. 2005; Nawawi et al. 2017b). Softwood is further lignified in its reaction wood, which normally develops with eccentric growth on the lower side of the inclined stem or branch and is referred to as compression wood (Timell 1983; Nawawi et al. 2016). The development of the compression 
wood is related to the generation of highly compressive growth stress (Yamamoto et al. 1991; Yamashita et al. 2007). The secondary walls of tracheids are thicker, and the lignin content is higher in the compression wood than in the opposite wood (Timell 1983). The compression wood lignin contains significant amounts of $p$-hydroxyphenyl units (H-units) in addition to the guaiacyl units (G-units) (Bland 1958, 1961; Timell 1986; Nanayakkara et al. 2009; Nawawi et al. 2017a). Whereas the H-units are deposited in the compound middle lamella in the early stages of cell wall formation in normal wood, they are distributed in both the compound middle lamella and the secondary wall in compression wood, which leads to highly lignified compression-wood tissues (Fukushima and Terashima 1991). A strong positive correlation between the $H / G$ ratio and lignin content has been found based on the lignin distribution within a pine compression wood disc determined by alkaline nitrobenzene oxidation $\left(\mathrm{NBO}, \mathrm{R}^{2}=0.98\right.$ between the lignin contents and the proportion of the $\mathrm{H}$-type product in all NBO products) (Nawawi et al. 2017a).

Via radical coupling reactions during lignin biosynthesis, G-units can couple at the carbon 5 (C5) position on its aromatic ring of the growing lignin polymer to form phenylcoumaran ( $\beta-5)$, biphenyl (5-5), and diaryl ether (4-0-5) structures (Figure 1), none of which can be formed only from S-units. Indeed, the variation in the S/G composition of lignin reflects the composition of different interunit linkage types (Karhunen et al. 1995; Ralph et al. 2006; Stewart et al. 2009; Kishimoto et al. 2010; Hirayama et al. 2019). Our previous study using the NBO method (Hirayama et al. 2019) also showed that the biphenyl contents in hardwood lignins varied widely depending on their S/G compositions. The yield of the biphenyl-type NBO products composed of two guaiacyl aromatic rings (GGbiphenyl products, e.g. dehydrodivanillin) was lower in the hardwoods than in the softwoods. In the 15 hardwood species, the GG-biphenyl product yield decreased with the increase in the ratio of S-units to the total S- and G-units $[S /(S+G)$ ratio] with a strong correlation (Hirayama et al.
2019). Biphenyl structures play a role in connecting two growing lignin polymers during lignin biosynthesis and can potentially be further coupled with monomers by radical coupling reactions to form a branched polymer. Much attention has been paid to the biphenyl structure content (Pew 1963; Drumond et al. 1989; Brunow et al. 1995; Capanema et al. 2004; Tamai et al. 2015; Hirayama et al. 2019), and the structural details of biphenyls in lignins have been investigated using different approaches to understand the polymer structures of lignins (Karhunen et al. 1995; Lundquist and Li 1999; Akiyama and Ralph 2009; Crestini et al. 2011).

A H-unit having no methoxy group can potentially be coupled both at the $\mathrm{C} 3$ and $\mathrm{C} 5$ positions on its aromatic ring, whereas the $\mathrm{C} 3$ position in the G-unit is already occupied by a methoxy group (Figure 1). Additional possible coupling sites in H-units could lead to the formation of more biphenyl structures, as well as the other condensedtype structures such as phenylcoumaran structures, than those of G-units. Indeed, a structural study of C3H-deficient alfalfa lignin (Ralph et al. 2006) revealed that an increase in the $\mathrm{H}$-unit content in the transgenic plant was accompanied by an increase in the relative abundance of phenylcoumaran and dibenzodioxocin structures in the different linkage types. In contrast, a nuclear magnetic resonance (NMR) study of the tracheary element lignin of HCT-deficient pine (Pinus radiata) showed the effect of $\mathrm{H}$-units in a different way (Wagner et al. 2007). In the transgenic plant, an increase in the relative abundance of resinols and a reduction in dibenzodioxocins was indicated together with an increase in the H-units compared with the wild type lignin composed of G-lignin. In the study of compression wood lignins by thioacidolysis, no significant difference in the relative abundance of condensed- and uncondensedtype structures was found in the lignins between the mature and immature compression wood tissues of Pinus thunbergii Parl. (Saito and Fukushima 2005).

In the present study, to investigate the influence of the $\mathrm{H} / \mathrm{G}$ ratio on the abundance of biphenyl and $\beta-5$ structures,

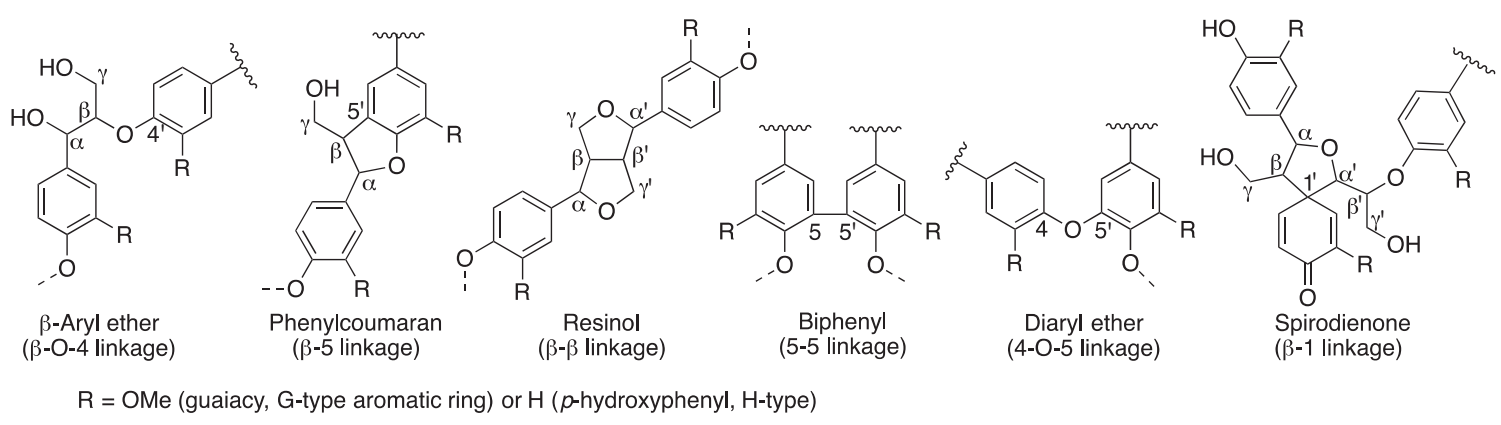

Figure 1: Various linkage types assumed to be present in compression wood lignins of angiosperms. 
we tried to characterize the compression wood lignin using the NBO method. Biphenyl-, $\beta$-5- and uncondensedtype NBO products carrying G- or H-type aromatic ring(s) were identified by comparison to authentic standard compounds, and their product yields were compared between compression and the opposite woods.

\section{Materials and methods}

Compression wood samples: Wood discs of three softwood species were collected from a leaning stem of Cryptomeria japonica D. Don (Japanese cedar) and a branch of Cedrus deodara (Lamb.) G. Don (Deodar cedar, Himalayan cedar) (Figure 2). The wood blocks were cut from each wood disc at six positions along the periphery of the disc. The position along the periphery was defined in angles, as shown in Figure 2, with $0^{\circ}\left(360^{\circ}\right)$ being on the lower side of the stem or branch (compression wood) and $180^{\circ}$ being on the upper side (opposite wood). Each wood block from the compression wood discs was ground in a Wiley mill (1-mm mesh screen), and the obtained wood meals were pre-extracted with an ethanol/benzene mixture $(1: 2, \mathrm{v} / \mathrm{v})$ for $6 \mathrm{~h}$ in a Soxhlet apparatus prior to chemical analyses. The pre-extracted wood meals were subjected to Klason lignin, methoxy $(\mathrm{MeO})$ group content determinations and NBO. The pre-extracted wood meals (Nawawi et al. 2017a) prepared from a wood disc of 30-cm diameter of Pinus merkusii Jungh et de Vriese (Sumatran pine) harvested in Indonesia were also used for the methoxy group determination of the Klason reside and NBO analyses.

Microscopic analysis: The wood blocks were soaked in water overnight, and, then, sliced in the radial direction with a sliding microtome (REM-710, Yamato Kohki, Saitama, Japan). Transverse sections with a thickness of approximately $15 \mu \mathrm{m}$ were observed with an optical microscope (BX50, Olympus Optical Co., Tokyo, Japan) equipped with a digital camera (Model D5000, Nikon Co., Tokyo, Japan) after staining with phloroglucinol-HCl (Wiesner reagent) (Nakano and Meshitsuka 1992).

Chemicals: Authentic model compounds for the NBO products of lignins (Figure 3 ) were synthesized. Dehydrodivanillin $\left(\mathrm{VV}_{\text {ald }}\right)$, dehydrovanillin-vanillic acid $\left(\mathrm{VV}_{\text {ald-acid }}\right)$ and dehydrodivanillic acid $\left(\mathrm{VV}_{\text {acid }}\right)$ were synthesized according to a previous report (Tamai et al. 2015). Dehydrovanillin-4-hydroxybenzaldehyde $\left(\mathrm{HV}_{\text {ald }}, 6,6^{\prime}\right.$-dihydroxy5-methoxy-[1,1'-biphenyl]-3,3'-dicarbaldehyde), $\quad$ 5-formylvanillin $\left(\mathrm{V}_{5-\mathrm{CHO}}\right)$, 5-carboxy vanillin $\left(\mathrm{V}_{5-\mathrm{COOH}}\right)$ and 5-formylvanillic acid $\left(\mathrm{VA}_{5-\mathrm{CHO}}\right)$ were synthesized as described below. The other authentic compounds, vanillin $\left(\mathrm{V}_{\text {ald }}\right)$, vanillic acid $\left(\mathrm{V}_{\text {acid }}\right)$, p-hydroxybenzaldehyde $\left(\mathrm{H}_{\text {ald }}\right)$, $p$-hydroxybenzoic acid $\left(\mathrm{H}_{\text {acid }}\right)$, 3-formyl-4-hydroxybenzaldehyde $\left(\mathrm{H}_{5-\mathrm{CHO}}\right)$, 3-carboxy-4-hydroxybenzaldehyde $\left(\mathrm{H}_{5-\mathrm{CoOH}}\right)$ and 3-carboxy4-hydroxybenzoic acid $\left(\mathrm{HA}_{5-\mathrm{coOH}}\right)$ were purchased from Fujifilm Wako Pure Chemical Co. (Osaka, Japan) or Tokyo Chemical Industry Co. (Tokyo, Japan). All other chemicals were of reagent grade.
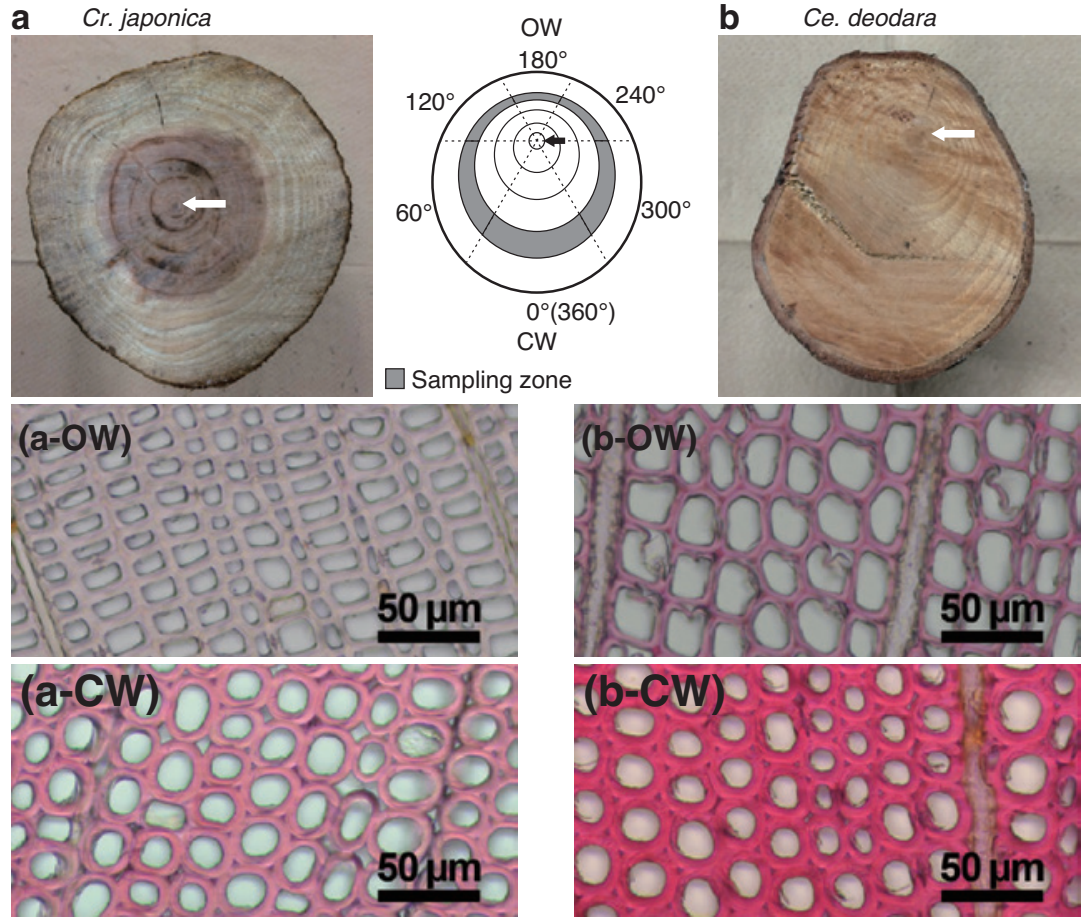

Figure 2: Cross sections of compression woods and photomicrographs of their transverse thin sections stained with phloroglucinol-HCl. (a) Disc of Cryptomeria japonica (Japanese cedar) from a leaning stem with 13-cm diameter and its photomicrographs at a peripheral position of $0^{\circ}$ (a-CW) and $180^{\circ}$ (a-OW). (b) Cedrus deodara (Himalayan cedar) disc of a branch with 8-cm diameter and its photomicrographs at $0^{\circ}(\mathrm{b}-\mathrm{CW})$ and $180^{\circ}(\mathrm{b}-\mathrm{OW})$. The peripheral position at $0^{\circ}\left(=360^{\circ}\right)$ on the lower side of a branch or leaning stems is the compression wood part (CW) and the position at $180^{\circ}$ is the opposite wood part (OW) in the diagram of the wood disc. The arrows in the pictures indicate the pith position showing that eccentric growth has occurred in the CWs. 
Wood meals (pre-extracted)

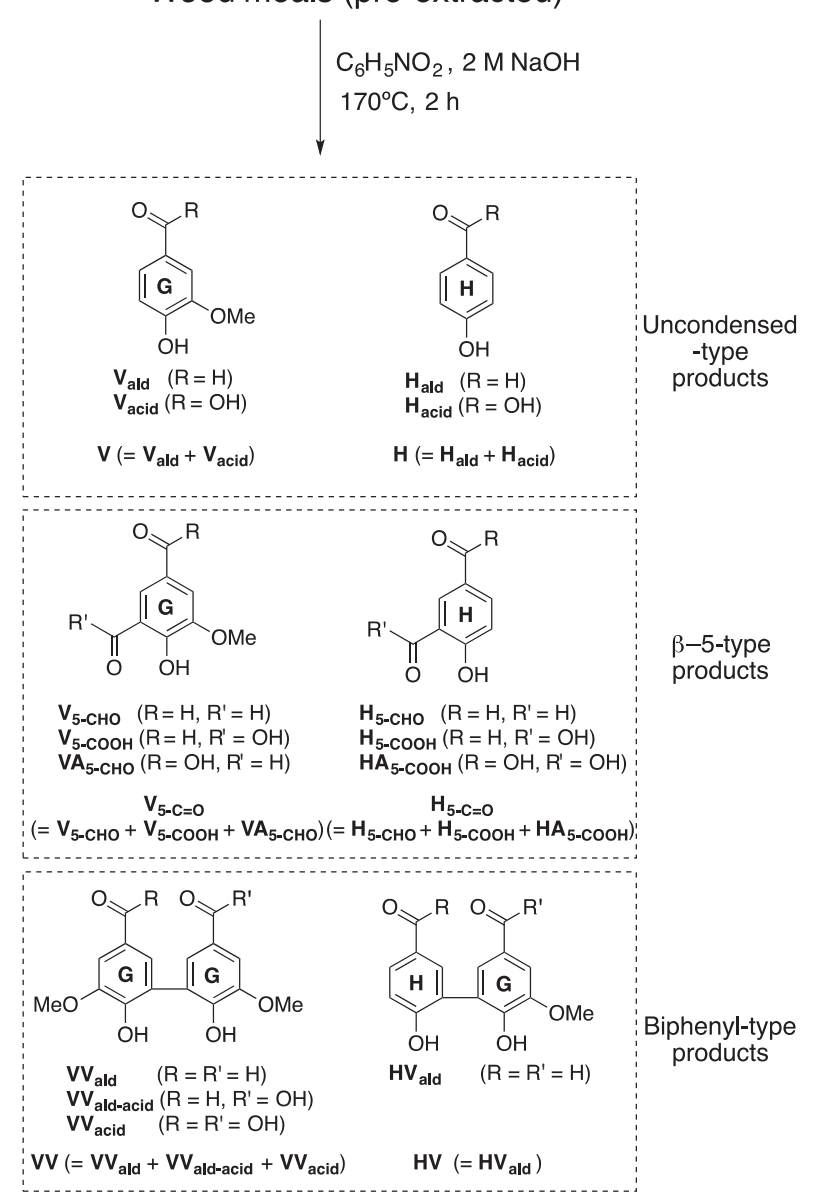

Figure 3: Alkaline nitrobenzene oxidation (NBO) products of wood meals determined in the present study.

NMR measurements: The NMR spectra of the synthesized compounds were recorded with a JEOL JNM-A500 $500 \mathrm{MHz}$ spectrometer (JEOL Ltd., Tokyo, Japan). The standard JEOL programs of one- and two-dimensional (proton, carbon, DEPT-135, ${ }^{1} \mathrm{H}^{-1} \mathrm{H}$ COSY, ${ }^{1} \mathrm{H}^{-13} \mathrm{C}$ HSQC and ${ }^{1} \mathrm{H}^{13} \mathrm{C}$ HMBC) NMR experiments were performed for the structural elucidation of the newly synthesized compounds. The central peak of the residual solvent was used as an internal reference $\left(\delta_{\mathrm{H}} 7.26\right.$, $\delta_{\mathrm{c}} 77.0 \mathrm{ppm}$ for $\mathrm{CDCl}_{3} ; \delta_{\mathrm{H}} 2.04, \delta_{\mathrm{c}} 29.8 \mathrm{ppm}$ for acetone- $d_{6}, \delta_{\mathrm{H}} 2.49, \delta_{\mathrm{c}}$ $39.5 \mathrm{ppm}$ for DMSO- $\left.d_{6}\right)$. The traditional numbering system for lignins (Sarkanen and Ludwig 1971; Ralph et al. 2004) was used rather than the systematic IUPAC numbering scheme.

Klason lignin content: The lignin content was determined as previously described as the sum of the Klason lignin content and the acid-soluble lignin content (Dence 1992). Pre-extracted wood meal (300 mg) was hydrolyzed with a $72 \% \mathrm{H}_{2} \mathrm{SO}_{4}$ solution (3 ml) for $3 \mathrm{~h}$ at room temperature (r.t.). The mixture was diluted with deionized water to obtain a $3 \% \mathrm{H}_{2} \mathrm{SO}_{4}$ solution, which was then autoclaved at $120^{\circ} \mathrm{C}$ for $30 \mathrm{~min}$. The resulting suspension was filtered through a fine glass filter, and the insoluble residue (Klason lignin) was dried at $105^{\circ} \mathrm{C}$ overnight and then weighed. The concentration of acid-soluble lignin in the filtrate was determined by measuring the UV absorption of the filtrate at $205 \mathrm{~nm}$ with an absorption coefficient of $110 \mathrm{l} \mathrm{g}^{-1} \mathrm{~cm}^{-1}$ (Swan 1965).
Methoxy group content: The methoxy group content of the insoluble residue obtained after Klason lignin determination was determined according to the method of Goto et al. $(2005,2006)$. Briefly, the Klason lignin residue $(30 \mathrm{mg})$ with $57 \%$ hydroiodic acid $(10 \mathrm{ml})$ was sealed in a vial with a rubber septum. The vial was placed in an oil bath at $130^{\circ} \mathrm{C}$ for $20 \mathrm{~min}$ with shaking and then cooled in an ice bath. Ethyl iodide $(0.1 \mathrm{mmol})$ in $\mathrm{CCl}_{4}$ was added through the septum as an internal standard. The mixture was extracted with cold $\mathrm{CCl}_{4}(10 \mathrm{ml})$. The organic layer was dried over $\mathrm{Na}_{2} \mathrm{SO}_{4}$, was analyzed by a gas chromatograph (GC)-flame ionization detector (FID) equipped with a fused-silica capillary column (CP-SIL 13CB, $0.32 \mathrm{~mm}$ i.d. $\times 25 \mathrm{~m}$ ) to determine the methyl iodide yield. The methoxy content is expressed as the yield of methyl iodide obtained from the Klason lignin residue.

Alkaline NBO of wood meals: Alkaline NBO (Chen 1992) was conducted according to the method for determining the biphenyl-type NBO products, although with a slightly modified workup procedure (Tamai et al. 2015). Wood meals ( $40 \mathrm{mg}$ ), $2 \mathrm{M} \mathrm{NaOH}$ solution $(7 \mathrm{ml}$ ) and nitrobenzene $(0.4 \mathrm{ml})$ were sealed in a $10-\mathrm{ml}$ stainless-steel autoclave and held at 170,190 or $210^{\circ} \mathrm{C}$ for $2 \mathrm{~h}$ in an oil bath with shaking. A temperature of $170^{\circ} \mathrm{C}$ and reaction time of $2 \mathrm{~h}$ was used unless otherwise noted. The autoclave was cooled with ice water and an aqueous $0.1 \mathrm{M}$ $\mathrm{NaOH}$ solution of ethyl vanillin (EV, 3-ethoxy-4-hydroxybenzaldehyde; $5 \mu \mathrm{mol}$ as $2.5 \mathrm{mM} \times 2 \mathrm{ml}$ ) was added to the reaction mixture as an internal standard. The reaction mixture was transferred into a separatory funnel with an aid of $0.1 \mathrm{M} \mathrm{NaOH}(15 \mathrm{ml})$ and washed with $\mathrm{CH}_{2} \mathrm{Cl}_{2}$ $(15 \mathrm{ml} \times 3)$. The aqueous layer was acidified with $2 \mathrm{M}$ hydrochloric acid and then extracted with $\mathrm{CH}_{2} \mathrm{Cl}_{2}(20 \mathrm{ml} \times 2)$ and diethyl ether $(20 \mathrm{ml})$ successively. The organic layers were combined, washed with water $(20 \mathrm{ml})$ and dried over $\mathrm{Na}_{2} \mathrm{SO}_{4}$. After filtration, the filtrate collected in a 100-ml pear-shaped flask was dried under reduced pressure. The residue was dissolved in pyridine $(200 \mu \mathrm{l})$, and around half the amount of the pyridine solution was transferred into a 1-ml vial with a screw cap and trimethylsilylated with bis(trimethylsilyl)acetamide (100 $\mu \mathrm{l})$ at $100^{\circ} \mathrm{C}$ for $10 \mathrm{~min}$. An aliquot of trimethylsilyl (TMS) derivatives $(2 \mu \mathrm{l})$ was analyzed by gas chromatography-mass spectroscopy (GC-MS) for the identification of the NBO products and by GC-FID for the quantification of the identified products.

GC/MS [electron ionization (EI), $70 \mathrm{eV}$ ] was carried out on Shimadzu GC2010/PARVUM2 (Shimadzu Co., Ltd., Kyoto, Japan) equipped with a fused-silica capillary column (IC-1, $0.25 \mathrm{~mm}$ i.d. $\times 30 \mathrm{~m}, 0.4 \mu \mathrm{m}$ thickness; GL Science Inc., Tokyo, Japan). The NBO products of the wood meals were identified by comparison with the retention times and mass spectra of authentic samples.

GC-FID was carried out on a Shimadzu GC-2014 (Shimadzu Co. Ltd.) equipped with a fused-silica capillary column (IC-1, $0.25 \mathrm{~mm}$ i.d. $\times 30 \mathrm{~m}, 0.4 \mu \mathrm{m}$ thickness; GL Science Inc.); carrier gas, helium; sprit ratio, 60; column flow rate, $1.83 \mathrm{ml} \mathrm{min}^{-1}$; injection temperature, $280^{\circ} \mathrm{C}$; detector temperature, $280^{\circ} \mathrm{C}$. Temperature program: $130^{\circ} \mathrm{C}$ (held for $10 \mathrm{~min}$ ), $\rightarrow 5^{\circ} \mathrm{C} \mathrm{min}{ }^{-1}$ to $145^{\circ} \mathrm{C}$ (held for $90 \mathrm{~min}$ ), $\rightarrow 10^{\circ} \mathrm{C} \mathrm{min}{ }^{-1}$ to $200^{\circ} \mathrm{C}$ (held for $40 \mathrm{~min}$ ), $\rightarrow 10^{\circ} \mathrm{C} \mathrm{m^{-1 }}$ to $215^{\circ} \mathrm{C}$ (held for $38 \mathrm{~min}$ ), $\rightarrow 5^{\circ} \mathrm{C} \mathrm{m^{-1 }}$ to $280^{\circ} \mathrm{C}$ (held for $10 \mathrm{~min}$ ). The total running time was $211.0 \mathrm{~min}$. Retention times: $8.4 \mathrm{~min}, \mathrm{H}_{\text {ald }} ; 14.9 \mathrm{~min}, \mathrm{~V}_{\text {ald }} ; 18.2 \mathrm{~min}, \mathrm{EV}$ (internal standard); $19.3 \mathrm{~min}, \mathrm{H}_{5 \text {-сно }}$; $21.9 \mathrm{~min}, \mathrm{H}_{\text {acid }} ; 34.5 \mathrm{~min}, \mathrm{~V}_{5-\text { - } \mathrm{CO}}$; $36.1 \mathrm{~min}, \mathrm{~V}_{\text {acid }} ; 37.5 \mathrm{~min}, \mathrm{H}_{5-\mathrm{CoOH}} ; 73.8 \mathrm{~min}, \mathrm{~V}_{5-\mathrm{CoOH}} ; 102.0 \mathrm{~min}, \mathrm{HA}_{5-\mathrm{coOH}}$; $103.8 \mathrm{~min}, \mathrm{VA}_{5 \text {-сно }} ; 146.8 \mathrm{~min}, \mathrm{HV}_{\text {ald }} ; 162.2 \mathrm{~min}, \mathrm{VV}_{\text {ald }} ; 182.9 \mathrm{~min}$, $\mathrm{VV}_{\text {ald-acid }} ; 196.3 \mathrm{~min}, \mathrm{VV}_{\text {acid }}$.

The products were quantified using the following calibration curves: $\mathrm{Y}=1.1510 \mathrm{X}+0.0099 \quad\left(\mathrm{R}^{2}=0.9995, \quad 0.0164 \leq \mathrm{X} \leq 1.40\right)$ for $H_{\text {ald }}, \quad Y=0.8498 X+0.0008 \quad\left(R^{2}=0.9998, \quad 0.00308 \leq X \leq 0.272\right)$ 
for $H_{\text {acid }}, \quad Y=1.0756 \mathrm{X}+0.0285 \quad\left(\mathrm{R}^{2}=0.9999, \quad 0.860 \leq \mathrm{X} \leq 7.01\right) \quad$ for $\mathrm{V}_{\text {ald }}, \quad \mathrm{Y}=0.8312 \mathrm{X}+0.0031 \quad\left(\mathrm{R}^{2}=1.0000, \quad 0.0919 \leq \mathrm{X} \leq 1.51\right)$ for $\mathrm{V}_{\text {acid }}$, $\mathrm{Y}=0.6034 \mathrm{X}+0.0015 \quad\left(\mathrm{R}^{2}=0.9989, \quad 0.00219 \leq \mathrm{X} \leq 0.519\right) \quad$ for $\quad \mathrm{HV}_{\text {ald }}$, $\mathrm{Y}=0.5646 \mathrm{X}-0.0043 \quad\left(\mathrm{R}^{2}=0.9994, \quad 0.00948 \leq \mathrm{X} \leq 0.973\right)$ for $\mathrm{VV}_{\text {ald }}$, $\mathrm{Y}=0.4905 \mathrm{X}+0.0017 \quad\left(\mathrm{R}^{2}=0.9871, \quad 0.0166 \leq \mathrm{X} \leq 0.182\right)$ for $\quad \mathrm{VV}_{\text {ald-acid }}$, $\mathrm{Y}=0.4221 \mathrm{X}+0.0005 \quad\left(\mathrm{R}^{2}=0.9992, \quad 0.00237 \leq \mathrm{X} \leq 0.251\right) \quad$ for $\quad \mathrm{VV}_{\text {acid }}$, $\mathrm{Y}=1.3155 \mathrm{X}+0.0081 \quad\left(\mathrm{R}^{2}=0.9983, \quad 0.00962 \leq \mathrm{X} \leq 0.198\right) \quad$ for $\mathrm{H}_{5-\mathrm{cHO}}$, $\mathrm{Y}=0.8730 \mathrm{X}+0.0009\left(\mathrm{R}^{2}=0.9999, \quad 0.00245 \leq \mathrm{X} \leq 0.254\right)$ for $\mathrm{H}_{5-\mathrm{cooH}}$, $\mathrm{Y}=0.6871 \mathrm{X}+0.0164\left(\mathrm{R}^{2}=0.9913,0.00895 \leq \mathrm{X} \leq 0.247\right)$ for $\mathrm{HA}_{5-\mathrm{cooH}}$, $\mathrm{Y}=1.1687 \mathrm{X}+0.0159 \quad\left(\mathrm{R}^{2}=0.9994, \quad 0.0265 \leq \mathrm{X} \leq 0.569\right) \quad$ for $\mathrm{V}_{5-\mathrm{CHO}}$, $\mathrm{Y}=0.8608 \mathrm{X}+0.0072 \quad\left(\mathrm{R}^{2}=0.9996, \quad 0.0484 \leq \mathrm{X} \leq 0.922\right)$ for $\mathrm{V}_{5-\mathrm{cooh}}$, $\mathrm{Y}=0.9276 \mathrm{X}+0.0171\left(\mathrm{R}^{2}=0.9989,0.00561 \leq \mathrm{X} \leq 0.157\right)$ for $\mathrm{VA}_{5 \text {-сно }}$. $\mathrm{Y}$ is the molar ratio of each authentic compound to $\mathrm{EV}$ (e.g. the $\mathrm{V}_{\text {ald }} / \mathrm{EV}$ molar ratio), and $\mathrm{X}$ is the GC area ratio of each authentic compound to $\mathrm{EV}$ (the $\mathrm{V}_{\text {ald }} / \mathrm{EV}$ area ratio).

The NBO products were categorized into uncondensed-type products carrying a H-unit $\left(\mathrm{H}=\mathrm{H}_{\text {ald }}+\mathrm{H}_{\text {acid }}\right)$ or a G-unit $\left(\mathrm{V}=\mathrm{V}_{\text {ald }}+\mathrm{V}_{\text {acid }}\right)$, biphenyl-type products carrying two G-units $\left(\mathrm{VV}=\mathrm{VV}_{\text {ald }}+\mathrm{VV}_{\text {ald-acid }}+\mathrm{VV}_{\text {acid }}\right)$, or a $\mathrm{H}$ - and a $\mathrm{G}$-units $\left(\mathrm{HV}=\mathrm{HV}_{\text {ald }}\right), \beta$-5-type products carrying a H-unit $\left(\mathrm{H}_{5-\mathrm{C}=\mathrm{O}}=\mathrm{H}_{5-\mathrm{CHO}}+\mathrm{H}_{5-\mathrm{COOH}}+\mathrm{HA}_{5-\mathrm{COOH}}\right)$ or a G-unit $\left(\mathrm{V}_{5-\mathrm{C}=\mathrm{O}}=\mathrm{V}_{5-\mathrm{CHO}}+\right.$ $\mathrm{V}_{5-\mathrm{COOH}}+\mathrm{VA}_{5-\mathrm{CHO}}$ ) (Figure 3). A $\mathrm{C}_{6}-\mathrm{C}_{3}$ unit with a molecular weight of $200 \mathrm{~g} \mathrm{~mol}^{-1}$ was used throughout to convert the moles of product per gram of lignin to moles per 100 moles of $\mathrm{C}_{6}-\mathrm{C}_{3}$ unit. Biphenyl products were derived from two $\mathrm{C}_{6}-\mathrm{C}_{3}$ units in the lignin; thus, the yield of $\mathrm{VV}$ was doubled to give a value of $2 \mathrm{VV}$, which express the number of $\mathrm{C}_{6}-\mathrm{C}_{3}$ units involved in the biphenyl structure.

Preparation of 5-carboxy vanillin $\left(\mathbf{V}_{5-\mathrm{coOH}}\right): \mathrm{V}_{5-\mathrm{COOH}}$ was synthesized by the Duff reaction according to a previous report (Morita 1964). $o$-Vanillin $(10.1 \mathrm{~g}, 60 \mathrm{mmol})$ and hexamethylenetetramine $(9.3 \mathrm{~g}, 66 \mathrm{mmol})$ were placed in a 300-ml round bottom flask with a reflux condenser and suspended in acetic acid $(80 \mathrm{ml})$. The mixture was refluxed in an oil bath for $4.5 \mathrm{~h}$. The reaction was monitored by thin-layer chromatography (TLC, $\mathrm{CH}_{2} \mathrm{Cl}_{2}-\mathrm{MeOH}, 10: 1, \mathrm{v} / \mathrm{v}$ ). The reaction mixture was concentrated under reduced pressure, and, then, $2 \mathrm{M} \mathrm{HCl}(120 \mathrm{ml})$ and diethyl ether $(60 \mathrm{ml})$ were added. The mixture was stirred for $2 \mathrm{~h}$ at r.t. and left to stand overnight. The resulting suspension was filtered through a Büchner funnel with suction. The residue was washed with water $(100 \mathrm{ml})$ and dried to afford $\mathrm{V}_{5-\mathrm{CоOH}}$ as brown crystals (4.9 g). Purification by silica-gel chromatography (EtOAc-acetone, 10:0 to 0:10), followed by recrystallization from EtOH-acetone $(2: 1, \mathrm{v} / \mathrm{v})$, gave $\mathrm{V}_{5 \text {-соон }}$ as light brown crystals. ${ }^{1} \mathrm{H}-\mathrm{NMR}$ (DMSO- $d_{6}, 500 \mathrm{MHz}$ ) $\delta_{\mathrm{H}}: 3.87$ (3H, s, OMe), $7.53(1 \mathrm{H}, \mathrm{d}, J=2.0 \mathrm{~Hz}, \mathrm{Ar} 2), 7.97$ (1H, d, $J=2.0 \mathrm{~Hz}, \operatorname{Ar6}), 9.83(1 \mathrm{H}, \mathrm{s}, \mathrm{CHO})$. ${ }^{13} \mathrm{C}-\mathrm{NMR}$ (DMSO- $d_{6}, 125 \mathrm{MHz}$ ) $\delta_{\mathrm{C}}: 55.93$ (OMe), 113.03 (Ar2), 113.19 (Ar5), 126.74 (Ar6), 127.48 (Ar1), 148.95 (Ar3), 156.97 (Ar4), 171.61 (COOH), 191.06 (CHO). GC-MS (70 eV) of TMS derivatives: $\mathrm{m} / \mathrm{z}=325$ (M-15).

Preparation of 5-formylvanillin $\left(\mathbf{V}_{5 \text { - } \mathrm{CHO}}\right)$ : The synthesis of $\mathrm{V}_{5 \text { - } \mathrm{CHO}}$ was also performed by the Duff reaction. Vanillin $(9.84 \mathrm{~g}, 65 \mathrm{mmol})$ and hexamethylenetetramine $(10.1 \mathrm{~g}, 71 \mathrm{mmol})$ were placed in a roundbottom flask fitted with a reflux condenser and suspended in acetic acid $(80 \mathrm{ml})$. The mixture was refluxed in an oil bath for $5.5 \mathrm{~h}$. The reaction mixture was concentrated under reduced pressure. Then, $2 \mathrm{M}$ hydrochloric acid $(120 \mathrm{ml})$ was added to the mixture, and the mixture was stirred for $2 \mathrm{~h}$ at r.t. The resulting reaction mixture was extracted with EtOAc $(100 \mathrm{ml} \times 3)$. The organic layers were combined, washed with brine, and dried over $\mathrm{Na}_{2} \mathrm{SO}_{4}$. After filtration, the filtrate was concentrated under vacuum. The residue $(5.6 \mathrm{~g})$ was separated by silica-gel chromatography with hexane-EtOAc (1:9 to $8: 2, \mathrm{v} / \mathrm{v})$ to afford compound formylvanillin as crystals (3.44 g, 32\%). ${ }^{1} \mathrm{H}$ NMR (acetone- $\left.d_{6}, 500 \mathrm{MHz}\right) \delta_{\mathrm{H}}: 3.98(3 \mathrm{H}, \mathrm{s}, \mathrm{OMe}), 7.64(1 \mathrm{H}, \mathrm{d}, J=1.9 \mathrm{~Hz}$, Ar2), 7.95 (1H, d, J=1.9 Hz, Ar6), 9.91 (1H, s, Ar1-CHO), 10.24 (1H, s, Ar5-CHO). ${ }^{13} \mathrm{C}$ NMR (acetone- $\left.d_{6}, 125 \mathrm{MHz}\right) \delta_{\mathrm{C}}: 56.68$ (OMe), 114.81 (Ar2), 122.00 (Ar5), 128.40 (Ar6), 130.10 (Ar1), 150.08 (Ar3), 157.19 (Ar4), 190.65 (Ar1-CHO), 195.30 (Ar5-CHO). GC-MS (70 eV) of TMS derivatives: $\mathrm{m} / \mathrm{z}=252(\mathrm{M})$ and $237(100)$.

Preparation of 5-formylvanillic acid $\left(\mathrm{VA}_{5-\mathrm{CH}}\right)$ : Using the Duff reaction, $\mathrm{VA}_{5-\mathrm{CHO}}$ was synthesized from vanillic acid and hexamethylenetetramine in a similar procedure to that used for the synthesis of $\mathrm{V}_{5-\mathrm{CoOH}}$ described above. ${ }^{1} \mathrm{H}$-NMR (DMSO- $d_{\sigma}$, $\left.500 \mathrm{MHz}\right) \delta_{\mathrm{H}}: 3.90$ (3H, s, OMe), $7.63(1 \mathrm{H}, \mathrm{d}$, $J=2.0 \mathrm{~Hz}, \mathrm{Ar}$ ), 7.87 (1H, d, $J=2.0 \mathrm{~Hz}, \mathrm{Ar} 6), 10.29$ (1H, s, CHO). ${ }^{13} \mathrm{C}-\mathrm{NMR}$ (DMSO- $\left.d_{6}, 125 \mathrm{MHz}\right) \delta_{\mathrm{C}}: 56.20$ (OMe), 116.39 (Ar2), 121.62 (Ar1), 121.96 (Ar5), 122.07 (Ar6), 148.36 (Ar3), 154.35(Ar4), 166.54 (COOH), 190.93 (CHO). GC-MS (70 eV) of TMS derivatives: $\mathrm{m} / \mathrm{z}=325$ (M-15).

Preparation of dehydrovanillin- $p$-hydroxybenzaldehyde $\left(\mathrm{HV}_{\text {ald }}\right)$ : $\mathrm{HV}_{\text {ald }}$ (1,1'-diformyl-4,4'-dihydroxy-3-methoxy-5,5'-biphenyl) was prepared by the NBO of a biphenyl compound, $\mathrm{HV}_{\alpha-\mathrm{CH} 3}$ (4,4'-dihydroxy1,1'-dimethyl-3-methoxy-5,5'-biphenyl), which was prepared by the oxidative coupling of $p$-cresol and $p$-creosol with ferric chloride (Reinhoudt et al. 1981). The separation of the NBO products was performed in acetate form to obtain the diacetate of $\mathrm{HV}_{\text {ald }}$, and, then, the purified diacetate was converted back to $\mathrm{HV}_{\text {ald }}$ by saponification.

Preparative NBO: In five 10-ml stainless steel autoclaves, compound $\mathrm{HV}_{\alpha-\mathrm{CH}}(0.098 \mathrm{~g}$ per each autoclave, $0.40 \mathrm{mmol})$ was sealed with $2 \mathrm{M} \mathrm{NaOH}$ ( $7 \mathrm{ml}$ each) and nitrobenzene ( $2 \mathrm{ml}$ each). The autoclaves were heated at $190^{\circ} \mathrm{C}$ for $20 \mathrm{~h}$ in an oil bath with shaking. The reaction mixtures originating from a total of $2 \mathrm{mmol}$ of compound $\mathrm{HV}_{\alpha-\mathrm{CH} 3}$ were combined in a separatory funnel, diluted with $0.1 \mathrm{M}$ $\mathrm{NaOH}(15 \mathrm{ml})$ and washed with $\mathrm{CH}_{2} \mathrm{Cl}_{2}(75 \mathrm{ml} \times 3)$. The aqueous layer was acidified with $2 \mathrm{M} \mathrm{HCl}$ and extracted with $\mathrm{CH}_{2} \mathrm{Cl}_{2}(100 \mathrm{ml} \times 2)$, followed by diethyl ether $(100 \mathrm{ml})$. The combined organic layer was washed with water $(100 \mathrm{ml})$ and dried over $\mathrm{Na}_{2} \mathrm{SO}_{4}$. After filtration, the filtrate was evaporated to dryness under reduced pressure.

Acetylation: The crude NBO products of compound $\mathrm{HV}_{\alpha-\mathrm{CH} 3}$ were acetylated with pyridine $(5 \mathrm{ml})$ and acetic anhydride $(5 \mathrm{ml})$ overnight at r.t. The reaction mixture was concentrated under reduced pressure at $50^{\circ} \mathrm{C}$. The remaining solvent was removed by repetition of the evaporation with EtOH to give $0.72 \mathrm{~g}$ of crude acetylated NBO product. Purification by silica-gel chromatography with a hexane-EtOAc eluent mixture afforded the diacetate of compound $\mathrm{HV}_{\text {ald }}$ (4,4' -di- $\mathrm{O}$-acetyl1,1'-diformyl-3-methoxy-5,5'-biphenyl), which is denoted $\mathrm{HV}_{\text {ald }}$ - $\mathrm{Ac}(0.15$ g, $21 \mathrm{~mol} \%$ yield from compound $\left.\mathrm{HV}_{\alpha-\mathrm{CH} 3}\right) .{ }^{1} \mathrm{H} \mathrm{NMR}\left(\mathrm{CDCl}_{3}, 500 \mathrm{MHz}\right)$ $\delta_{\mathrm{H}}: 2.08$ (3H, s, $\mathrm{CH}_{3} \mathrm{CO}$ ), 2.12 (3H, s, $\mathrm{CH}_{3} \mathrm{CO}$ ), 3.95 (3H, s, OMe), $7.39[1 \mathrm{H}$, d, $J=8 \mathrm{~Hz}, 3$ position on $p$-hydroxyphenyl aromatic ring (H-3)], 7.43 $(1 \mathrm{H}, \mathrm{d}, J=2 \mathrm{~Hz}), 7.56(1 \mathrm{H}, \mathrm{d}, J=2 \mathrm{~Hz}), 7.85(1 \mathrm{H}, \mathrm{d}, J=2 \mathrm{~Hz}), 7.98(1 \mathrm{H}, \mathrm{dd}$, $J=8,2 \mathrm{~Hz}, \mathrm{H}-2)$, 9.97 (1H, s, CHO), 10.02 (1H, s, CHO).

Deacetylation: To a dioxane solution of the diacetate $\mathrm{HV}_{\text {ald }}-\mathrm{Ac}$ ( $0.15 \mathrm{~g}, 0.42 \mathrm{mmol}$ in $1.2 \mathrm{ml}$ dioxane), $1 \mathrm{M} \mathrm{NaOH}$ (1.7 ml) was added and stirred for $4 \mathrm{~h}$ at r.t. The reaction progress was monitored by TLC (hexane-EtOAc, 1:2, v/v). The reaction solution was acidified with $1 \mathrm{M}$ $\mathrm{HCl}$, and the resulting suspension was filtered through a fine glass filter. The insoluble part was washed with water and dried under vacuum to afford compound $\mathrm{HV}_{\text {ald }}$ as a powder $(0.097 \mathrm{~g}, 85 \mathrm{~mol} \%$ yield from compound $\mathrm{HV}_{\text {ald }}$-Ac). ${ }^{1} \mathrm{H}$ NMR (DMSO- $\left.d_{6}, 500 \mathrm{MHz}\right) \delta_{\mathrm{H}}: 3.91(3 \mathrm{H}$, s, OMe), $7.07[1 \mathrm{H}, \mathrm{d}, J=8 \mathrm{~Hz}, 3$ position on a $p$-hydroxyphenyl aromatic ring $(\mathrm{H}-3)], 7.41[1 \mathrm{H}, \mathrm{d}, J=2 \mathrm{~Hz}, 2$ position on a guaiacyl aromatic ring (G-2)], 7.42 (1H, d, J=2 Hz, G-6), $7.70(1 \mathrm{H}, \mathrm{d}, J=2 \mathrm{~Hz}, \mathrm{H}-6), 7.76$ (1H, dd, $J=8,2 \mathrm{~Hz}, \mathrm{H}-2), 9.79$ (1H, s, CHO on G-ring), 9.81 (1H, s, CHO on 
H-ring). ${ }^{13} \mathrm{C}$ NMR (DMSO- $\left.d_{6}, 125 \mathrm{MHz}\right), \delta_{\mathrm{C}}: 56.12$ (OMe), 109.21 (G-2), 116.18 (H-3), 124.84 (G-5), 125.10 (H-5), 127.88 (G-1), 128.23 (H-1), 128.32 (G-6), 131.07 (H-2), 133.80 (H-6), 148.26 (G-3), 150.54 (G-4), 161.01 (H-4), 191.28 (CHO on a H-ring), 191.44 (CHO on a G-ring).

\section{Results and discussion}

The tracheids of the lower side of the compression woods at the $0^{\circ}$ peripheral position (CW) on the discs of $\mathrm{Cr}$. japonica and Ce. deodara were round in shape with thick cell walls (Figure 2), which is characteristic of compression wood. In contrast, the tracheids of the opposite wood at $180^{\circ}$ (OW) were rectangular in shape with thinner cell walls. Pre-extracted wood meals were prepared from the six peripheral positions of the two wood discs and subjected to chemical analyses. The pre-extracted wood meals of a P. merkusii compression wood disc, which has been previously reported (Nawawi et al. 2017a), were also analyzed. As shown in Table 1 and Figure 4, the three compression wood discs exhibited the typical distribution pattern of lignin content, methoxy group content,

Table 1: Lignin content, the methoxy group content of the Klason lignin residues, and the yields of NBO products obtained from compression wood stems of Japanese cedar (Cr. japonica), Merkus pine (P. merkusii) and a branch of Deodar cedar (Ce. deodara).

\begin{tabular}{|c|c|c|c|c|c|c|}
\hline \multirow{2}{*}{$\frac{\text { Species }}{\text { Sample position }\left({ }^{\circ}\right)^{\mathrm{a}}}$} & \multicolumn{2}{|c|}{ Cr. japonica } & \multicolumn{2}{|c|}{ Ce. deodara } & \multicolumn{2}{|c|}{ P. merkusil } \\
\hline & $0^{\circ} \mathrm{CW}^{\mathrm{a}}$ & $180^{\circ} O W^{a}$ & $0^{\circ} \mathrm{CW}$ & $180^{\circ} \mathrm{OW}$ & $0^{\circ} \mathrm{CW}$ & $180^{\circ} \mathrm{OW}$ \\
\hline Lignin $^{\mathrm{b}}(w t \%)$ & 42.0 & 34.5 & 36.3 & 30.1 & 34.9 & 27.5 \\
\hline $\mathrm{MeO}^{\mathrm{c}}\left(\mathrm{mol} 200 \mathrm{~g}^{-1}\right)$ & 0.80 & 0.93 & 0.73 & 0.89 & 0.77 & 1.00 \\
\hline \multicolumn{7}{|l|}{ NBO ${ }^{d}$ products ( $\mu \mathrm{mol} 1 \mathrm{~g}^{-1}$ lignin) } \\
\hline \multicolumn{7}{|l|}{ Uncondensed type } \\
\hline $\mathrm{V}_{\text {ald }}$ & 1405 & 1940 & 1381 & 1788 & 1441 & 1796 \\
\hline $\mathrm{V}_{\text {acid }}$ & 107 & 125 & 108 & 122 & 125 & 138 \\
\hline $\mathbf{V}\left(\mathrm{V}_{\text {ald }}+\mathrm{V}_{\text {acid }}\right)$ & 1512 & 2065 & 1489 & 1910 & 1566 & 1934 \\
\hline $\mathrm{H}_{\text {ald }}$ & 233 & 17 & 251 & 34 & 224 & 40 \\
\hline $\mathrm{H}_{\text {acid }}$ & 21 & 2 & 22 & 2 & 24 & 4 \\
\hline $\mathbf{H}\left(\mathrm{H}_{\text {ald }}+\mathrm{H}_{\text {acid }}\right)$ & 254 & 19 & 273 & 36 & 248 & 44 \\
\hline Subtotal $(\mathbf{V}+\mathbf{H})$ & 1766 & 2084 & 1762 & 1946 & 1814 & 1978 \\
\hline (of total, \%) & $(79 \%)$ & $(79 \%)$ & (79\%) & $(80 \%)$ & $(82 \%)$ & $(82 \%)$ \\
\hline \multicolumn{7}{|l|}{$\beta-5$ type } \\
\hline $\mathrm{V}_{5 \text { - } \mathrm{CHO}}$ & 81 & 121 & 82 & 109 & 69 & 88 \\
\hline $\mathrm{V}_{5-\mathrm{COOH}}$ & 45 & 47 & 39 & 42 & 34 & 40 \\
\hline $\mathrm{VA}_{5-\mathrm{CHO}}$ & 18 & 23 & 16 & 20 & 15 & 20 \\
\hline$V_{5-\mathrm{C}=0}\left(V_{5-\mathrm{CHO}}+V_{5-\mathrm{COOH}}+V^{-} A_{5 H O}\right)$ & 144 & 191 & 137 & 171 & 118 & 148 \\
\hline $\mathrm{H}_{5-\mathrm{CHO}}$ & 11 & 8 & 10 & 3 & 8 & 2 \\
\hline $\mathrm{H}_{5-\mathrm{COOH}}$ & 11 & 5 & 9 & 3 & 13 & 6 \\
\hline $\mathrm{HA}_{5-\mathrm{COOH}}$ & $\mathrm{nd}^{\mathrm{f}}$ & $\mathrm{nd}^{\mathrm{f}}$ & $n d^{f}$ & $\mathrm{nd}^{\mathrm{f}}$ & $n d^{f}$ & $n d^{f}$ \\
\hline $\mathrm{H}_{5-\mathrm{C}=0}\left(\mathrm{H}_{5-\mathrm{CHO}}+\mathrm{H}_{5-\mathrm{COOH}}+\mathrm{HA}_{5-\mathrm{COOH}}\right)$ & 22 & 13 & 19 & 6 & 21 & 8 \\
\hline Subtotal $\left(\mathbf{V}_{5-c=0}+\mathbf{H}_{5-C=0}\right)$ & 166 & 204 & 156 & 177 & 139 & 156 \\
\hline (of total, \%) & $(7 \%)$ & (8\%) & $(7 \%)$ & $(7 \%)$ & $(6 \%)$ & $(6 \%)$ \\
\hline \multicolumn{7}{|l|}{ 5-5 type } \\
\hline $2 \mathrm{VV}_{\text {ald }}$ & 224 & 287 & 210 & 264 & 187 & 235 \\
\hline $2 \mathrm{VV}_{\text {ald-acid }}$ & 49 & 53 & 45 & 51 & 42 & 49 \\
\hline $2 \mathrm{VV}_{\text {acid }}$ & 3 & 6 & 3 & 4 & 3 & 3 \\
\hline $2 \mathrm{VV}\left(2 \mathrm{VV}_{\text {ald }}+2 \mathrm{VV}_{\text {ald-acid }}+2 \mathrm{VV}_{\text {acid }}\right)$ & 276 & 346 & 258 & 319 & 232 & 287 \\
\hline $2 \mathrm{HV}_{\text {ald }}(=\mathbf{2 H V})$ & 43 & 5 & 54 & 11 & 39 & 15 \\
\hline Subtotal $(2 \mathrm{VV}+2 \mathrm{HV})$ & 320 & 351 & 312 & 330 & 271 & 302 \\
\hline (of total, \%) & $(14 \%)$ & (13\%) & (14\%) & $(13 \%)$ & $(12 \%)$ & $(12 \%)$ \\
\hline Total $^{\mathrm{g}}$ & 2252 & 2639 & 2230 & 2453 & 2224 & 2436 \\
\hline$(\%)^{e}$ & (100\%) & $(100 \%)$ & (100\%) & $(100 \%)$ & (100\%) & $(100 \%)$ \\
\hline
\end{tabular}

aPeripheral degree on the wood discs (see Figure 2 for the details), CW, compression wood part; OW, the opposite wood part. bignin content $=$ Klason lignin + acid-soluble lignin. 'Methoxy $(\mathrm{MeO})$ group content of the Klason lignin was expressed as the value per phenylpropanoid $\left(C_{6}-C_{3}\right)$ unit on the assumption that the molecular weight of $C_{6}-C_{3}$ unit is $200 \mathrm{~g} \mathrm{~mol}^{-1}$. dYield of nitrobenzene oxidation (NBO) products based on the Klason lignin content. eRelative yield in all NBO products. ${ }^{\mathrm{f}}$ Not detected. ${ }^{9}$ Total yield of NBO products; Total $=\mathbf{V}+\mathbf{H}+\mathbf{V}_{5-\mathrm{C}=0}+\mathbf{H}_{5-\mathrm{C}=0}+\mathbf{2} \mathbf{V V}+\mathbf{2} \mathbf{H V}$. $\mathbf{V}=\mathrm{V}_{\text {ald }}+\mathrm{V}_{\text {acid }}, \mathrm{H}=\mathrm{H}_{\text {ald }}+\mathrm{H}_{\text {acid }}, \mathbf{V}_{5-\mathrm{C}=0}=\mathrm{V}_{5-\mathrm{CHO}}+\mathrm{V}_{5-\mathrm{COOH}}+\mathrm{VA}_{5-\mathrm{CHO}}, \mathrm{H}_{5-\mathrm{C}=\mathrm{O}}=\mathrm{H}_{5-\mathrm{CHO}}+\mathrm{H}_{5-\mathrm{COOH}}+\mathrm{HA}_{5-\mathrm{COOH}}, 2 \mathrm{VV}=2 \mathrm{VV}_{\text {ald }}+2 \mathrm{VV}_{\text {ald-acid }}+2 \mathrm{VV}_{\text {acid }}, 2 \mathrm{HV}=2 \mathrm{HV}_{\text {ald }}$ 

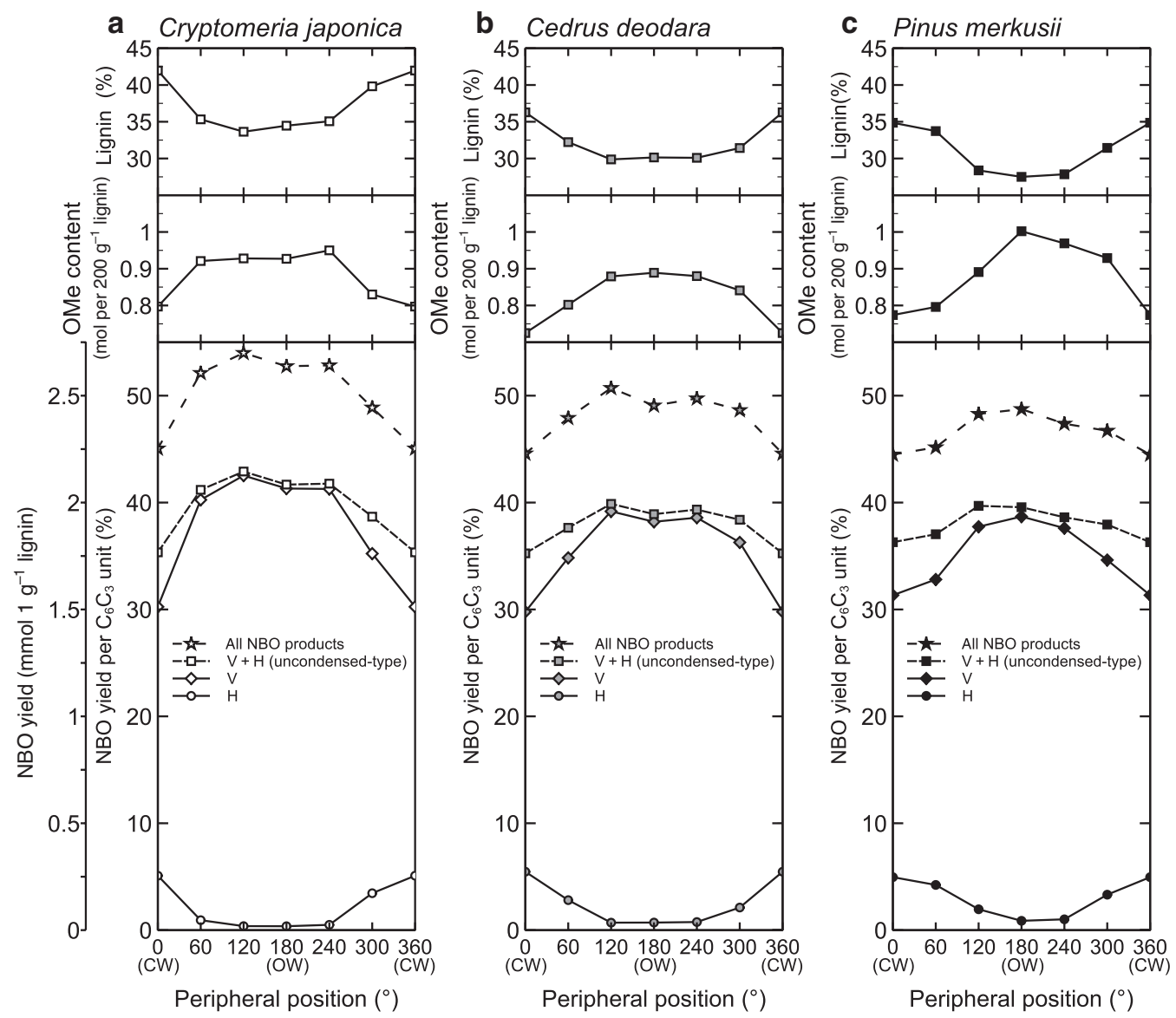

Figure 4: Distributions of lignin contents, the methoxy group contents of the Klason lignin, and the yields of NBO products within the compression wood disc of (a) Cr. japonica, (b) Ce. deodara and (c) P. merkusii.

The peripheral position $0^{\circ}$ and $180^{\circ}$ are the compression wood part (CW) and the opposite wood part (OW), respectively (see Figure 1 for the details). For the NBO products, the yields of $\mathrm{G}$ - and $\mathrm{H}$-type uncondensed products ( $\mathrm{V}$ and $\mathrm{H}$ ), and the total of all $\mathrm{NBO}$ products $\left(\mathrm{V}+\mathrm{H}+\mathrm{H}_{5-\mathrm{C}=0}+\right.$ $\mathrm{V}_{5-\mathrm{c}=0}+2 \mathrm{VV}+2 \mathrm{HV}$ ) are shown. The biphenyl product yield ( $\mathrm{VV}$ and $\mathrm{HV}$ ) was doubled to $2 \mathrm{VV}$ and $2 \mathrm{HV}$ so that the NBO yield represents the yield per aromatic ring. MeO: methoxy group contents (mol per $200 \mathrm{~g}$-Klason lignin).

and yields of uncondensed-type products obtained by the NBO method (H and V) for compression wood (Bland 1958, 1961; Timell 1986; Lapierre et al. 1988; Yeh et al. 2006; Nanayakkara et al. 2009; Nawawi et al. 2017a). The lignin content determined by the Klason lignin method was the highest in the compression wood part $\left(0^{\circ}\right)$ and tended to decrease towards the opposite wood part $\left(180^{\circ}\right)$. The methoxy group content of the Klason residue was lowest in the compression wood part $\left(0^{\circ}\right)$, indicating that the $\mathrm{H} / \mathrm{G}$ ratio was higher in this part than in the opposite wood part (Figure 4). The H:G ratios were calculated based on the methoxy group content in the compression wood part $\left(0^{\circ}\right)$ and were found to be 20:80 for Cr. japonica, 27:73 for Ce. deodara, and 23:77 for P. merkusii on the assumption that the molecular weight of one phenylpropanoid $\left(\mathrm{C}_{6}-\mathrm{C}_{3}\right)$ unit is $200 \mathrm{~g} \mathrm{~mol}^{-1}$ (Table 1). For uncondensed-type NBO products, the $\mathrm{G}$-type $\left(\mathrm{V}=\mathrm{V}_{\text {ald }}+\mathrm{V}_{\text {acid }}\right)$ and the $\mathrm{H}$-type product yields $\left(\mathrm{H}=\mathrm{H}_{\text {ald }}+\mathrm{H}_{\text {acid }}\right)$ were the lowest and highest, respectively, in the compression wood part $\left(0^{\circ}\right)$.

\section{Effect of reaction conditions on the yields of NBO products}

Chan et al. (1995) pointed out in their study of the NBO method using simple model compounds that an H-type model gives NBO products in much lower yield than Gand S-type models, for example, the NBO products were obtained in yields of $4.4 \mathrm{~mol} \%\left(\mathrm{H}_{\text {ald }}\right), 65.2 \mathrm{~mol} \%\left(\mathrm{~V}_{\text {ald }}\right)$, and $71.7 \mathrm{~mol} \%$ (syringaldehyde, $\mathrm{S}_{\text {ald }}$ ) from 1-(4-hydroxyphenyl) ethanol, apocynol, and 1-(4-hydroxy-3,5-dimethoxyphenyl)ethanol, respectively, after reaction at $170^{\circ} \mathrm{C}$ for $2 \mathrm{~h}$. Iiyama and Lam (1990) reported in their model study for the application of the NBO method to grass lignins that 
the H-type NBO product yield obtained from $p$-coumaric acid $\left(\mathrm{H}_{\text {ald }}+\mathrm{H}_{\text {acid }}, 62 \mathrm{~mol} \%, 2 \mathrm{~h}\right.$ at $\left.170^{\circ} \mathrm{C}\right)$ was lower than the $\mathrm{G}$-type product yield from ferulic acid $\left(\mathrm{V}_{\text {ald }}+\mathrm{V}_{\text {acid }}, 72 \mathrm{~mol} \%\right)$. Min et al. (2015) employed an NBO reaction temperature of $170^{\circ} \mathrm{C}$ for softwood and hardwood samples, and a more severe temperature of $190^{\circ} \mathrm{C}$ for a non-woody material (corn stover), which contains a substantial amount of the $p$-coumaric acid moiety in the cell wall, to improve the $\mathrm{H}_{\text {ald }}$ yield.

We examined the NBO of compression wood treated for $2 \mathrm{~h}$ at 170,190 and $210^{\circ} \mathrm{C}$ to examine if the H-type product yields from biphenyl and $\beta-5$ structures would increase under more severe reaction conditions than the conventional reaction conditions $\left(170^{\circ} \mathrm{C}, 2 \mathrm{~h}\right)$. As shown in Figure 5, all H- and G-type NBO products were lower under the severe conditions $\left(210^{\circ} \mathrm{C}\right)$ than at 170 and $190^{\circ} \mathrm{C}$. This result is similar to the previous results for the NBO of aspen wood lignins, which are composed of the G- and S-units reported by Kavanagh and Pepper (1955), in which the maximum yield of vanillin and syringaldehyde was obtained at temperature of $170-180^{\circ} \mathrm{C}$, and became significantly lower at 200 and $215^{\circ} \mathrm{C}$. Although the H-type product yields $\left(\mathrm{H}, 2 \mathrm{HV}\right.$, and $\left.\mathrm{H}_{5-\mathrm{C}=0}\right)$ were slightly higher after treatment at $190^{\circ} \mathrm{C}$ than at $170^{\circ} \mathrm{C}$, the increase was not significant (Figure 5). For the characterization of the biphenyl and $\beta-5$ structures in the present study, we used $170^{\circ} \mathrm{C}$ for $2 \mathrm{~h}$, which is within the range of conventional reaction conditions $\left(170-180^{\circ} \mathrm{C}\right.$ for $\left.2-3 \mathrm{~h}\right)$ (Chen 1992).

\section{Biphenyl-type products}

Our previous study using the NBO method indicate that the biphenyl content of lignin is very similar in normal wood

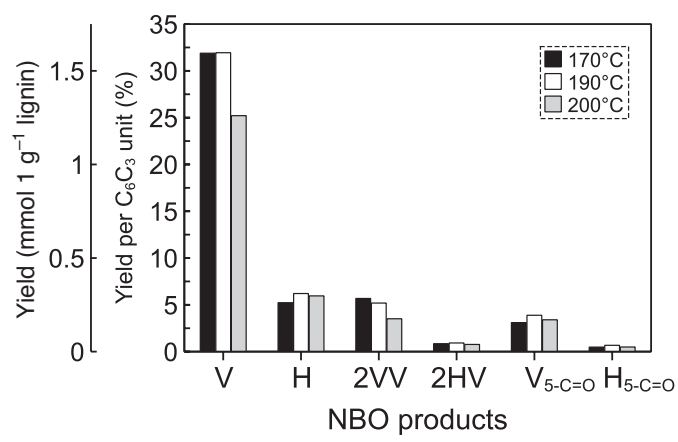

Figure 5: Influence of the reaction temperature on the NBO product yields of the compression wood (reaction condition of 170,190 , or $210^{\circ} \mathrm{C} \times 2 \mathrm{~h}$ ).

The wood meals used were prepared from the compression wood part of the $\mathrm{Cr}$. japonica wood disc (peripheral position $0^{\circ}$ ) shown in Figure 2. of six softwood species on the basis of the GG-biphenyl product yields (Hirayama et al. 2019). Within the small variations of the NBO product yields, a negative correlation was found between the GG-biphenyl product yields and the $\mathrm{H} / \mathrm{G}$ composition ratio among the six softwood species, but the correlation was only moderate, possibly because of the low, and narrow range of $\mathrm{H}$-unit contents in these normal wood lignins. The H-type product yields were $0.6-2.3 \mathrm{~mol} \%$ of all NBO products, and the methoxy group contents of their lignins were also in a narrow range of 0.97-1.07 mol per $200 \mathrm{~g}$-Klason lignin in the softwood species (Hirayama et al. 2019).

A H-unit having no methoxy group has two coupling sites on the ring at the $\mathrm{C} 3$ and $\mathrm{C} 5$ positions. Therefore, one may suppose that the biphenyl content would be higher in compression wood lignins containing a significant number of $\mathrm{H}$-units, especially considering that $\mathrm{H}$-units have greater probability of forming biphenyls and other condensed-type structures than G-units.

When the GG-biphenyl product yield (VV) was doubled to give $2 \mathrm{VV}$ so that the NBO yield represents the yield of aromatic rings, the GG-biphenyls account for approximately $7 \%$ of the phenylpropanoid units $\left(0.07 / \mathrm{C}_{6}-\mathrm{C}_{3}\right)$ in the opposite wood of the $\mathrm{Cr}$. japonica sample $\left(180^{\circ}\right.$ peripheral angle in Figure 2$)$. This number, $2 \mathrm{VV}$, decreased towards the compression wood part at $0^{\circ}$ peripheral (Figure 6a). The GG-biphenyl yield was plotted against the values representing the $H / G$ ratio of their lignins (Figures 6a, 7-a1 and 7-b1). As indicators of the $\mathrm{H} / \mathrm{G}$ ratio, both the methoxy group content of the Klason lignin residue and the $\mathrm{H} /(\mathrm{H}+\mathrm{G})$ ratio calculated from all NBO products were used (Figure 7). The latter is the proportion of $\mathrm{H}$-type aromatic rings $\left(\mathrm{H}+\mathrm{H}_{5-\mathrm{C}=0}+\mathrm{HV}\right)$ in the total of $\mathrm{H}-$ and G-type aromatic rings $\left(\mathrm{V}+\mathrm{H}+\mathrm{V}_{5-\mathrm{C}=\mathrm{O}}+\mathrm{H}_{5-\mathrm{C}=\mathrm{O}}+2 \mathrm{HV}+2 \mathrm{VV}\right)$ contained in the NBO products and is called the $p$-hydroxyphenyl ratio $(\mathrm{H}$ ratio) in the present study. The GG-biphenyl yield (VV) decreased with increase in the $p$-hydroxyphenyl ratio and with the decrease in the methoxy group content. $\left(\mathrm{R}^{2}=0.99\right.$, in Figures 6a, 7-a1 and 7-b1).

As a biphenyl-type NBO product carrying both guaiacyl (G)- and p-hydroxyphenyl (H)-units (HG-biphenyl product), dehydrovanillin- $p$-hydroxybenzaldehyde $\left(\mathrm{HV}_{\text {ald }}\right.$, in Figure 3) was identified as a novel NBO product by the comparison with an authentic sample. The decrease in the GG-biphenyl yield (VV) in the compression wood part (in Figure 6a) was largely offset by the increase in the HG-biphenyl product (HV). As a result, the total content of biphenyl products $(\mathrm{VV}+\mathrm{HV})$ was similar at different peripheral positions of the compression wood disc (Figure 6a). In Figure 6, numbers 2HV and 2VV are plotted 
a

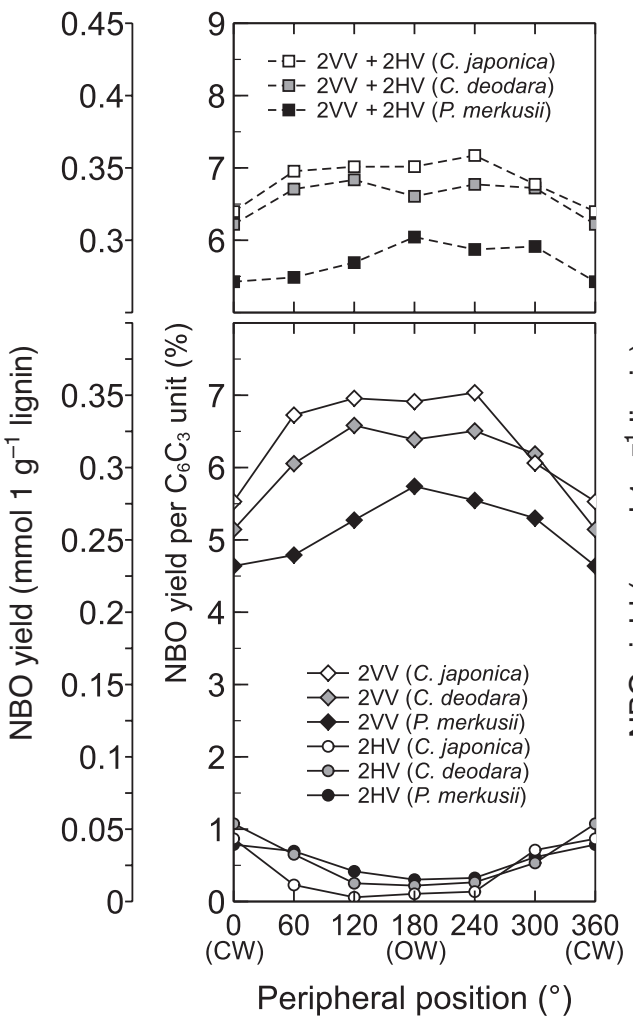

b

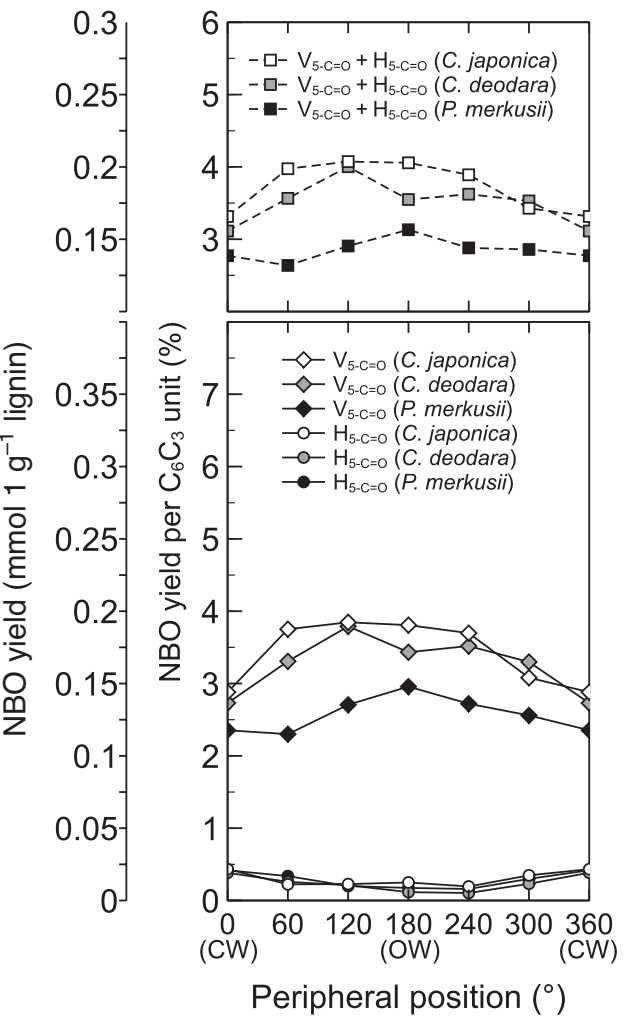

Figure 6: Yields of biphenyl and $\beta$-5-type NBO products obtained from the compression woods of three softwood species. (a) GG- and HG-biphenyl products ( $2 \mathrm{VV}$ and $2 \mathrm{HV}$ ) and (b) $\mathrm{G}$ - and $\mathrm{H}-\beta$ - 5 -type products $\left(\mathrm{V}_{5-\mathrm{C}=0}\right.$ and $\left.\mathrm{H}_{5-\mathrm{C}=0}\right)$.

The biphenyl product yield (VV and $\mathrm{HV}$ ) was doubled to $2 \mathrm{VV}$ and $2 \mathrm{HV}$ so that the NBO yield represents the yield per aromatic ring. The peripheral positions of $0^{\circ}$ and $180^{\circ}$ are the compression wood part (CW) and the opposite wood part (OW), respectively.

instead of $\mathrm{HV}$ and $\mathrm{VV}$ to indicate the number of aromatic rings in the biphenyl products.

Biphenyl-type products carrying two $\mathrm{H}$-units $(\mathrm{HH}-$ biphenyl product) would be present in the NBO products. Although a candidate peak for dehydrodi- $p$-hydroxybenzaldehyde $\left(\mathrm{HH}_{\text {ald }}\right)$ was found in the NBO products of wood meals by GC-MS analysis, its peak intensity was much weaker than those of the $\mathrm{VV}_{\text {ald }}$ and $\mathrm{HV}_{\text {ald }}$ peaks. The preparation of authentic $\mathrm{HH}_{\text {ald }}$, which is required for the identification of the NBO products, was not achieved in the present study.

The compression woods of the other two species also exhibited similar distribution patterns of biphenyl products in the wood disc (Figures 6a and 7). The GG- and HG-biphenyl yields were the lowest and highest, respectively, in the compression wood part $\left(0^{\circ}\right.$ peripheral degree). As shown in Figures 7-a1, 7-a2, 7-b1 and 7-b2, the GG- and HG-biphenyl yields were decreased and increased, respectively, with increase in the $p$-hydroxyphenyl ratio (or with decrease in the methoxy group content). Consequently, the total yields of biphenyl-products (VV + HV) were similar among the six peripheral positions of each disc (Figure 6a) although the total yields are not constant and seem to be slightly lower in the compression wood part than in the opposite wood part.

\section{$\beta$-5-type products}

In an early study of the NBO method, $\mathrm{V}_{5-\mathrm{CHO}}$ and $\mathrm{V}_{5-\mathrm{COOH}}$ were isolated from the NBO products of spruce wood meal using a multistep purification procedure (Leopold 1952; Pew 1955). Their yields were much lower than the yield of vanillin $\left(\mathrm{V}_{\text {ald }}\right)$ : $0.23 \mathrm{wt} \%$ for $\mathrm{V}_{5 \text {-CHO }}, 1.2 \mathrm{wt} \%$ for $\mathrm{V}_{5-\mathrm{CoOH}}$, and $27.5 \mathrm{wt} \%$ for $\mathrm{V}_{\text {ald }}$ on the basis of the lignin content of wood (Leopold 1952). From a $\beta-5$ model compound, dehydrodiisoeugenol, $\mathrm{V}_{5-\mathrm{COOH}}$ was also isolated in a low yield of $7.5 \%$ as an NBO product (Pew 1955).

In addition to $\mathrm{V}_{5-\mathrm{CHO}}$ and $\mathrm{V}_{5 \text {-СоОн }}$, in the present study, 5-formylvanillic acid $\left(\mathrm{VA}_{5 \text {-сно }}\right.$ in Figure 6) was obtained, which was identified by GC-MS analysis in the NBO 


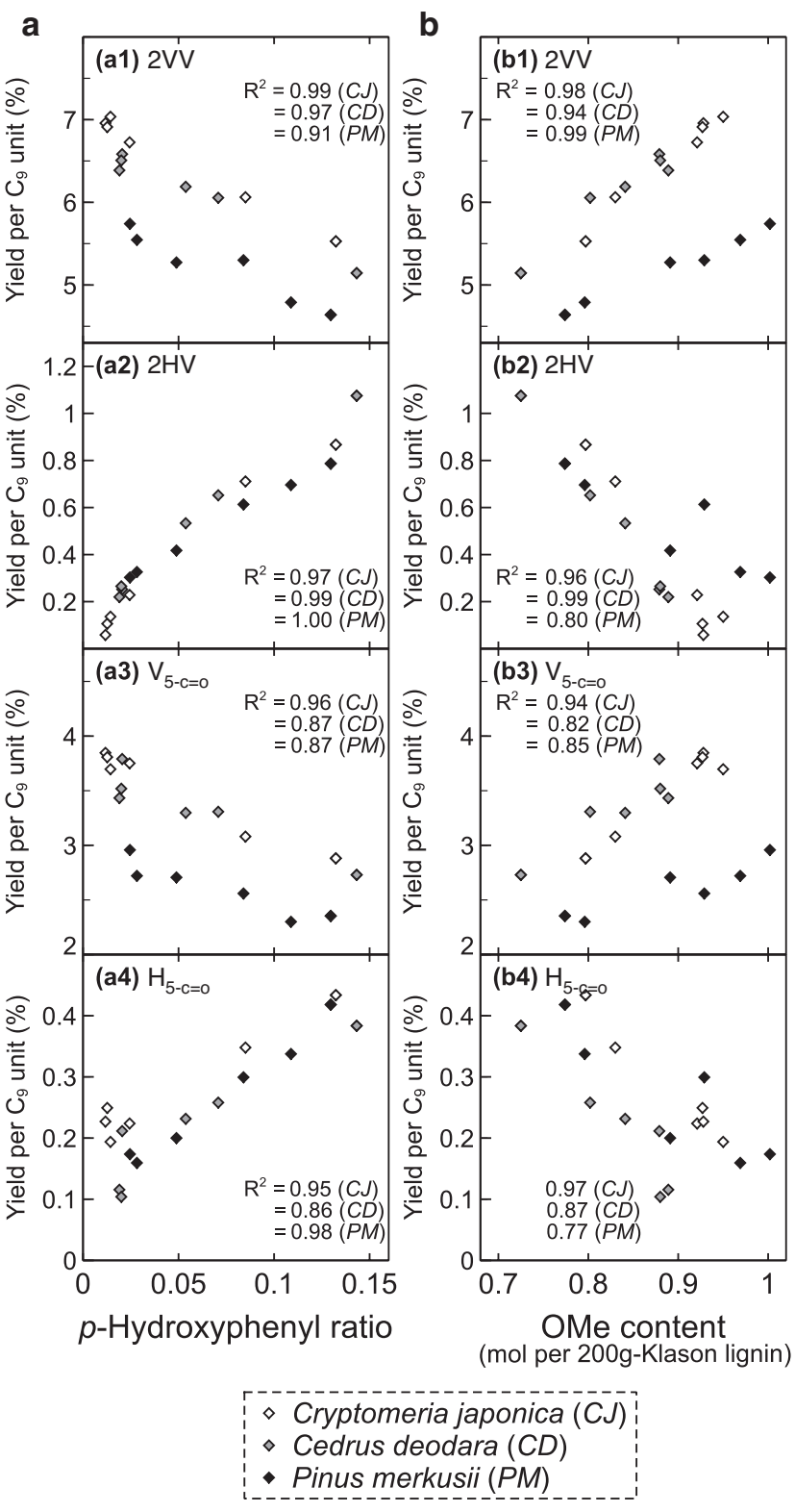

Figure 7: Relationship between the $p$-hydroxyphenyl/guaiacyl (H/G) ratio and the yields of biphenyl and $\beta$-5-type NBO products.

(a) The $p$-hydroxyphenyl ratio determined by the NBO method and (b) the $\mathrm{MeO}$ group content of the Klason residue was used as an indicator of the $\mathrm{H} / \mathrm{G}$ ratio of lignin. (a1 and b1) GG-biphenyl products (2VV), (a2 and b2) HG-biphenyl product (2HV), (a3 and b3) $\mathrm{G}$ - $\beta$ - 5 -type products $\left(\mathrm{V}_{5-\mathrm{C}=0}\right)$, and (a4 and b4) $\mathrm{H}-\beta$ - 5 -type products $\left(\mathrm{H}_{5-\mathrm{C}=0}\right)$. The $p$-hydroxyphenyl ratio is the proportion of all the H-type products $\left(\mathrm{H}+\mathrm{H}_{5-\mathrm{C}=0}+\mathrm{HV}\right)$ to the total of all products $\left(\mathrm{V}+\mathrm{H}+\mathrm{H}_{5-\mathrm{C}=0}+\mathrm{V}_{5}\right.$. $\mathrm{c}=0+2 \mathrm{VV}+2 \mathrm{HV}$ ), representing the molar ratio of $\mathrm{H}$-units to the total of $\mathrm{G}$ - and $\mathrm{H}$-units detected as NBO products. The biphenyl product yield ( $\mathrm{VV}$ and $\mathrm{HV}$ ) was doubled to $2 \mathrm{VV}$ and $2 \mathrm{HV}$ so that the NBO yield represents the yield per aromatic ring.

products of the wood meals by comparison with authentic standard compounds. Among these $\beta$-5-type NBO products carrying a G-unit (G- $\beta$-5-type product), $\mathrm{V}_{5 \text {-Сно }}$ was the main product $\left(\mathrm{V}_{5-\text { - } \mathrm{HO}}: \mathrm{V}_{5-\mathrm{COOH}}: \mathrm{VA}_{5-\mathrm{CHO}}\right.$ was approximately 5:2:1, Table 1). Two $\beta$-5-type NBO products carrying an H-unit (H- $\beta$-5-type product in Figure 6) were also identified, which were 5-formyl- $p$-hydroxybenzaldehyde $\left(\mathrm{H}_{5-\mathrm{CHO}}\right)$ and 5-carboxy- $p$-hydroxybenzaldehyde $\left(\mathrm{H}_{5 \text { - } \mathrm{CoOH}}\right)$. These $\mathrm{H}-\beta$-5-type products were obtained in comparable yields by the NBO of the compression wood samples. Although we tried to find 5-carboxy- $p$-hydroxybenzoic acid $\left(\mathrm{HA}_{5}\right.$. ${ }_{\mathrm{COOH}}$ ) in the NBO products, the corresponding peak was not found in the GC-MS analysis by comparison with the authentic compound.

The total yield of the $\beta$-5-type product $\left(\mathrm{H}_{5-\mathrm{C}=0}+\mathrm{V}_{5-\mathrm{C}=0}\right)$ represents $0.03-0.04 / C_{9}$ of lignins and was significantly lower than that of the uncondensed-type products $(\mathrm{H}+\mathrm{V})$ or twice the biphenyl-type product yield $(2 \mathrm{VV}+2 \mathrm{HV})$ (Figure $6 \mathrm{~b}$ ). The relative yields of the $\beta$-5-type products in all NBO products were approximately $7 \%$. This low yield partially may reflect the conversion rate from the $\beta$-5-structures in lignin into the corresponding $\beta$-5-type product $\left(\mathrm{V}_{5-\mathrm{C}=0}\right)$ by the NBO method. On the basis of the previous model studies (Kavanagh and Pepper 1955; Pew 1955; Lee et al. 1988; Iiyama and Lam 1990; Tamai et al. 2015), the conversion rate of the $\beta$-5-structures is assumed to be significantly lower than those of the $\beta-0-4$ and biphenyl structures. Considerably high conversion rates have been reported for biphenyl model compounds (yield of NBO VV products of approximately $70 \mathrm{~mol} \%$ ) (Pew 1955; Tamai et al. 2015) and for a $\beta$-O-4 model (V, approximately 60-90 mol\%) (Kavanagh and Pepper 1955; Lee et al. 1988; Iiyama and Lam 1990; Tamai et al. 2015). In contrast, a low conversion rate of $7.5 \%$ was reported for dehydrodiisoeugenol into $\mathrm{V}_{5 \text { - } \mathrm{COOH}}$ as described above (Pew $1955)$, although the yields of the other $\beta$-5-type products (e.g. $\mathrm{V}_{5-\text { Сно }}$ ), which could possibly be a main product, were not reported. Further detailed model experiments using $\beta$-5-model compounds will be required to validate the yields obtained from the wood samples.

The distribution patterns of the $\beta$-5-type product yields in the wood discs were similar to those of the biphenyl product yields. The yield of the G- $\beta$-5-type-product $\left(\mathrm{V}_{5-\mathrm{C}=0}\right)$ was lower in the compression wood part $\left(0^{\circ}\right.$ position) than the opposite wood part $\left(180^{\circ}\right)$. The yield of $\mathrm{H}-\beta$-5-type products $\left(\mathrm{H}_{5-\mathrm{C}=0}\right)$ was lower than the G- $\beta-5$ type-product yield $\left(\mathrm{V}_{5-\mathrm{C}=0}\right)$ and tended to be higher in the compression wood than in the opposite wood. The Gand $\mathrm{H}-\beta$ - 5 -type product yields decreased and increased, respectively, along with an increase in the $p$-hydroxyphenyl ratio (Figure 7-a4) or with a decrease in the methoxy group content (Figure 7-b4). Thus, the decrease in the $\mathrm{V}_{5-\mathrm{C}=0}$ yield was partially offset by the increase in the $\mathrm{H}_{5-\mathrm{C}=0}$ yield, which resulted in a small difference in the total 
of the $\beta$-5-type product $\left(\mathrm{V}_{5-\mathrm{C}=0}+\mathrm{H}_{5-\mathrm{C}=0}\right)$ within each wood disc. The total yields $\left(\mathrm{V}_{5-\mathrm{C}=0}+\mathrm{H}_{5-\mathrm{C}=0}\right)$ tended to be slightly lower in the opposite wood than the compression wood (Figure 6b).

The distribution patterns of the $\mathrm{H}$ - and $\mathrm{G}-\beta-5$-type products must reflect the structural characteristics of the lignins in the wood discs. However, the distribution pattern of the total of the $\beta$-5-type product yields, which were slightly lower in the compression wood part $\left(0^{\circ}\right)$, may not directly represent the structural nature of the lignins in compression wood discs considering the similar distribution patterns of the other NBO products shown in Figure $6 \mathrm{~b}$ and the previous results, which suggested a possibly low conversion rate of H-type lignins into NBO products (Iiyama and Lam 1990; Chan et al. 1995; Min et al. 2015). All three types of products (uncondensed-, $\beta-5-$, and biphenyl-types) showed a similar distribution pattern for their yields in each wood disc (Table 1, and Figures 4 and 6). As a result, a clear negative correlation between the total yield of all NBO products and the $\mathrm{H} / \mathrm{G}$ ratios indicators was obtained $\mathrm{R}^{2}=0.98$ (Cr. japonica), 0.94 (Ce. deodara) and 0.86 (P. merkusii) vs. the $p$-hydroxyphenyl ratio. $\mathrm{R}^{2}=0.91$ (Cr. japonica), 0.91 (Ce. deodara), and 0.75 (P. merkusii) vs. OMe content). In addition, the proportion of $\mathrm{H}$-units to the total of $\mathrm{H}$ - and G-units in all the NBO products (i.e. the $p$-hydroxyphenyl ratio), which was $13-$ $14 \%$ in the compression wood parts $\left(0^{\circ}\right)$ of the three wood discs, was significantly lower than the proportions of the $\mathrm{H}$-units calculated based on the methoxy group content of the Klason lignin (20-27\%), implying that the H-type lignin structures did not efficiently yield NBO products compared with the G-type lignin structures under the NBO employed in the present study $\left(170^{\circ} \mathrm{C}, 2 \mathrm{~h}\right)$.

\section{Relative abundance of biphenyl and $\beta-5$ structures in compression woods}

The distribution pattern of the biphenyl and $\beta-5$ structures within a wood disc was evaluated based on the relative yields of the NBO products. Notably, the relative yields of uncondensed-, biphenyl- and $\beta$-5-type products $\left[(\mathrm{V}+\mathrm{H}):(2 \mathrm{HV}+2 \mathrm{VV}):\left(\mathrm{V}_{5-\mathrm{C}=0}+\mathrm{H}_{5-\mathrm{C}=0}\right)\right]$ were very similar in the six peripheral positions of each compression wood disc (Table 1 and Figure 8). Because the conversion rate of a corresponding original structure into its $\mathrm{NBO}$ product is expected to be different from each other, the proportion in the Table 1 does not directly indicate the actual proportion of the corresponding original structures in the lignin sample. For example, even though the relative yield of biphenyl-type products is higher than that of $\beta$-5-type

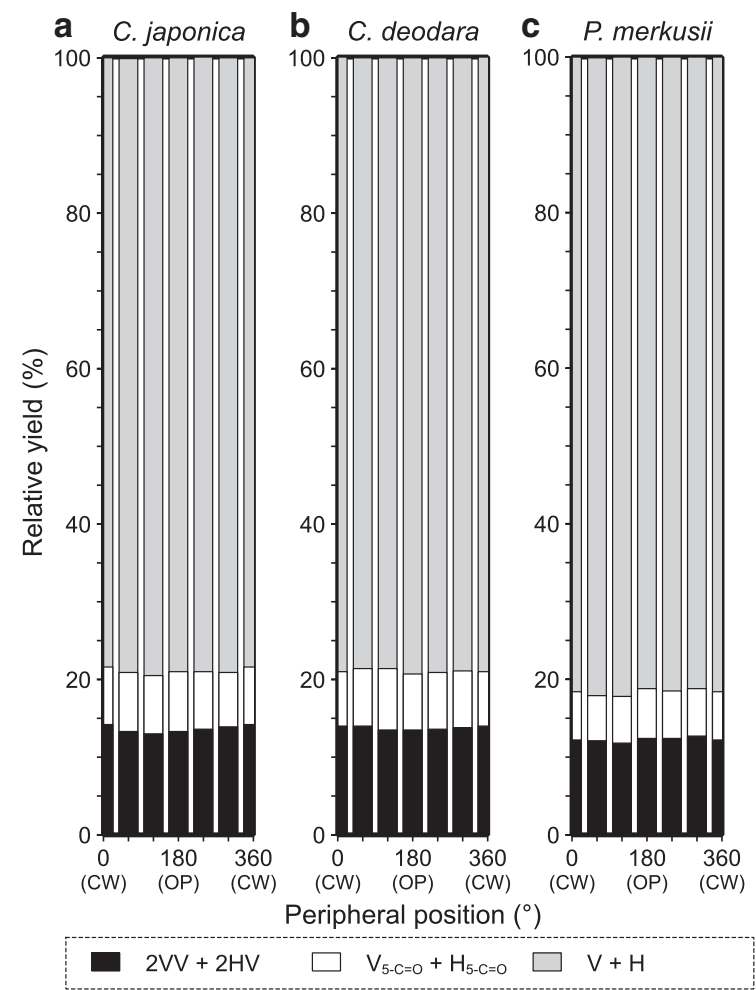

Figure 8: Relative yields of the biphenyl- and $\beta$-5- and uncondensed-type NBO products obtained from the compression wood disc of (a) Cr. japonica, (b) Ce. deodara, and (c) P. merkusii. The peripheral positions of $0^{\circ}$ and $180^{\circ}$ are the $\mathrm{CW}$ and the $\mathrm{OW}$, respectively. Biphenyl-type products, $2 \mathrm{VV}+2 \mathrm{HV} ; \beta$-5-type products, $\mathrm{V}_{5-\mathrm{C}=0}+\mathrm{H}_{5-\mathrm{C}=0}$; and uncondensed-type products, $\mathrm{V}+\mathrm{H}$. The biphenyl product yield ( $\mathrm{VV}$ and $\mathrm{HV}$ ) was doubled to $2 \mathrm{VV}$ and $2 \mathrm{HV}$ so that the NBO yield represents the yield per aromatic ring.

products in a lignin sample, this does not necessarily mean that the proportion of biphenyl structure in the particular lignin is higher than that of $\beta$-5-structure. However, if the relative yield of biphenyl-type products in one sample is higher than that in another sample, it is suggested that the former sample is richer in biphenyl structures than the latter sample. As shown in Figure 8, in spite of the change of H-unit content from compression wood part to the opposite wood part within the a wood disc, the variation of the molar ratio of $(\mathrm{V}+\mathrm{H}):(2 \mathrm{HV}+2 \mathrm{VV}):\left(\mathrm{V}_{5-\mathrm{C}=0}+\mathrm{H}_{5-\mathrm{C}=0}\right)$ in six peripheral positions was very small: $78.9( \pm 0.5): 13.6$ $( \pm 0.6): 7.4( \pm 0.4)$ for Cr. japonica, $79.0( \pm 0.4): 13.8( \pm 0.3): 7.3$ $( \pm 0.6)$ for Ce. deodara and $81.6( \pm 0.6): 12.3( \pm 0.5): 6.1( \pm 0.3)$ for $P$. merkusii. These results suggest that a higher proportion of H-unit does not necessarily result in a higher proportion of condensed-type structures in the compression wood samples. In order to verify this suggestion, further investigation using different lignin model compounds is required, especially on the conversion rate of $\mathrm{H}$-type structures into NBO products. This will provide useful 
information to understand why the total yield of all the NBO products, including uncondensed-, biphenyl-, and $\beta$-5-type products, was lower in the compression wood part than in the opposite wood part.

A similar result was also reported in a previous study of the differentiating xylem of compression wood by the thioacidolysis method (Saito and Fukushima 2005), i.e. no significant difference was observed for the proportion of biphenyl and $\beta-5$ structures when the $H / G$ ratio in lignins increased during the maturation of the compression wood xylem. In contrast, in an NMR study of isolated lignins highly enriched in $\mathrm{H}$-units (H-unit content: 65-99\%) from transgenic alfalfa (Medicago sativa L.) (Ralph et al. 2006) and Arabidopsis thaliana lines (Weng et al. 2010; Bonawitz et al. 2014), significant changes in the lignin substructures were observed based on comparison with the lignins of the wild-type plants or other transgenic lines. In the case of the A. thaliana lines (Weng et al. 2010), compared with the isolated G-type lignin of Arabidopsis, the H-type lignin contained a lower proportion of $\beta-0-4$ structures and a higher proportion of phenylcoumaran (an 1.5fold increase) and resinol (a three-fold increase) linkage types (Weng et al. 2010). It is interesting that no significant differences in the relative abundances of biphenyl and $\beta-5$ structures was found between the compression wood and the opposite wood, even though the lignins of compression woods examined here contain a significant proportion of H-units (20-27\% based on the methoxy group content).

\section{Conclusions}

On the basis of the NBO product yields, HG-type biphenyl and $\mathrm{H}$-type $\beta-5$ structures were more abundant in the compression wood lignins, which have a higher $\mathrm{H} / \mathrm{G}$ ratio, than the opposite wood. However, the increases seem to be offset by the decreases in the GG-biphenyl and G-type $\beta-5$ structures in the compression wood. The relative abundances of biphenyl and $\beta-5$ structures were similar between the compression wood and the opposite wood even though the compression wood lignin contains substantial numbers of $\mathrm{H}$-units. These results indicate that the enhancement of $p$-hydroxyphenyl unit does not necessarily result in an increased content of condensed-type structures.

Author contributions: All the authors have accepted responsibility for the entire content of this submitted manuscript and approved submission.
Research funding: This work was supported by the Japan Science and Technology Agency (JST), PRESTO (JPMJPR12B1), the Grant-in-Aid for Japan Society for the Promotion of Science (JSPS) Research Fellow (15J08385), and the Grant-in-Aid for Challenging Exploratory Research (15K14767) from the Ministry of Education, Culture, Sports, Science, and Technology of Japan (MEXT).

Employment or leadership: None declared.

Honorarium: None declared.

\section{References}

Akiyama, T., Ralph, J. (2009) Exploring branch-points in lignin; NMR chemical shift characteristics of nonphenolic vs phenolic dibenzodioxocin model compounds. Proceedings of 15th International Symposium on Wood, Fibre and Pulping Chemistry ISWFPC. Oslo, Norway. ID number: 0-008.

Akiyama, T., Goto, H., Nawawi, D.S., Syafii, W., Matsumoto, Y., Meshitsuka, G. (2005) Erythro/threo ratio of $\beta$-0-4-structures as an important structural characteristic of lignin. Part 4: variation in the erythro/threo ratio in softwood and hardwood lignins and its relation to syringyl/guaiacyl ratio. Holzforschung 59:276-281.

Bland, D.E. (1958) The chemistry of reaction wood. Part I. The lignins of Eucalyptus goniocalyx and Pinus radiata. Holzforschung 12:36-43.

Bland, D.E. (1961) The chemistry of reaction wood. Part III. The milled wood lignins of Eucalyptus goniocalyx and Pinus radiata. Holzforschung 15:102.

Bonawitz, N.D., Kim, J.I., Tobimatsu, Y., Ciesielski, P.N., Anderson, N.A., Ximenes, E., Maeda, J., Ralph, J., Donohoe, B.S., Ladisch, M., Chapple, C. (2014) Disruption of mediator rescues the stunted growth of a lignin-deficient Arabidopsis mutant. Nature 509:376.

Brunow, G., Karhunen, P., Lundquist, K., Olson, S., Stomberg, R. (1995) Investigation of lignin models of the biphenyl type by X-ray crystallography and NMR spectroscopy. J. Chem. Crystallogr. 25:1-10.

Capanema, E.A., Balakshin, M.Y., Kadla, J.F. (2004) A comprehensive approach for quantitative lignin characterization by NMR spectroscopy. J. Agric. Food. Chem. 52:1850-1860.

Chan, F.D., Nguyen, K.L., Wallis, A.F.A. (1995) Contribution of lignin sub-structures to nitrobenzene oxidation products. J. Wood Chem. Technol. 15:329-347.

Chen, C.L. (1992) Nitrobenzene and cupric oxide oxidation. In: Methods in Lignin Chemistry. Eds. Lin, S.Y., Dence, C.W. SpringerVerlag, Berlin. pp. 301-321.

Crestini, C., Melone, F., Sette, M., Saladino, R. (2011) Milled wood lignin: a linear oligomer. Biomacromolecules 12:3928-3935.

Dence, C.W. (1992) The determination of lignin. In: Methods in Lignin Chemistry. Eds. Lin, S.Y., Dence, C.W. Springer-Verlag, Berlin. pp. 33-61.

Drumond, M., Aoyama, M., Chen, C.L., Robert, D. (1989) Substituent effects on C-13 chemical-shifts of aromatic carbons in biphenyl type lignin model compounds. J. Wood Chem. Technol. 9:421-441. 
Fukushima, K., Terashima, N. (1991) Heterogeneity in formation of lignin. Part XV: Formation and structure of lignin in compression wood of Pinus thunbergii studied by microautoradiography. Wood Sci. Technol. 25:371-381.

Goto, H., Koda, K., Tong, G., Matsumoto, Y., Meshitsuka, G. (2005) Formation of methyl iodide from methoxyl-free compounds by hydriodic acid treatment. J. Wood Sci. 51:312-314.

Goto, H., Koda, K., Tong, G., Matsumoto, Y., Meshitsuka, G. (2006) Interference of carbohydrates in the determination of the methoxyl content of lignin in woody samples. J. Wood Chem. Technol. 26:81-93.

Hirayama, H., Akiyama, T., Tamai, A., Nawawi, D.S., Syafii, W., Yokoyama, T., Matsumoto, Y. (2019) Variation of the contents of biphenyl structures in lignins among wood species. Holzforschung. 73:569-578.

liyama, K., Lam, T.B.T. (1990) Lignin in wheat internodes 1. The reactivities of lignin units during alkaline nitrobenzene oxidation. J. Sci. Food Agric. 51:481-491.

Karhunen, P., Rummakko, P., Sipilä, J., Brunow, G. (1995) Dibenzodioxocins; A novel type of linkage in softwood lignins. Tetrahedron Lett. 36:169-170.

Kavanagh, K.R., Pepper, J.M. (1955) The alkaline nitrobenzene oxidation of aspen wood and lignin model substances. Can. J. Chem. 33:24-30.

Kishimoto, T., Chiba, W., Saito, K., Fukushima, K., Uraki, Y., Ubukata, M. (2010) Influence of syringyl to guaiacyl ratio on the structure of natural and synthetic lignins. J. Agric. Food. Chem. 58:895-901.

Lapierre, C., Monties, B., Rolando, C. (1988) Thioacidolyses of diazomethane-methylated pine compression wood and wheat straw in situ lignins. Holzforschung 42:409-411.

Lee, Y.L., Tachibana, S., Sumimoto, M. (1988) Mechanochemistry of lignin I. Alkaline-nitrobenzene oxidation of dimeric lignin model compounds. Mokuzai Gakkaishi 34:34-41.

Leopold, B. (1952) Studies on lignin 3. Oxidation of wood from Picea abies (L) Karst (Norway spruce) with nitrobenzene and alkali. Acta Chem. Scand. 6:38-48.

Lundquist, K., Li, S. (1999) Structural analysis of lignin and lignin degradation products. Proceedings of 10th International Symposium on Wood, and Pulping Chemistry ISWFPC. Yokohama, Japan. pp. 2-10.

Min, D.Y., Xiang, Z.Y., Liu, J., Jameel, H., Chiang, V., Jin, Y.C., Chang, H.M. (2015) Improved protocol for alkaline nitrobenzene oxidation of woody and non-woody biomass. J. Wood Chem. Technol. 35:52-61.

Morita, H. (1964) An alternative synthesis of 5-carboxyvanillin. Can. J. Chem. 42:2362-2363.

Nakano, J., Meshitsuka, G. (1992) Detection and determination. In: Methods in Lignin Chemistry. Eds. Lin, S.Y., Dence, C.W. Springer-Verlag, Berlin. pp. 23-61.

Nanayakkara, B., Manley-Harris, M., Suckling, I.D., Donaldson, L.A. (2009) Quantitative chemical indicators to assess the gradation of compression wood. Holzforschung 63:431-439.

Nawawi, D.S., Syafii, W., Akiyama, T., Matsumoto, Y. (2016) Characteristics of guaiacyl-syringyl lignin in reaction wood in the gymnosperm Gnetum gnemon L. Holzforschung 70:593-602.

Nawawi, D.S., Akiyama, T., Syafii, W., Matsumoto, Y. (2017a) Characteristic of $\beta$-0-4 structures in different reaction wood lignins of Eusideroxylon zwageri T. et B. and four other woody species. Holzforschung 71:11-20.

Nawawi, D.S., Syafii, W., Tomoda, I., Uchida, Y., Akiyama, T., Yokoyama, T., Matsumoto, Y. (2017b) Characteristics and reactivity of lignin in acacia and eucalyptus woods. J. Wood Chem. Technol. 37:273-282.

Pew, J.C. (1955) Nitrobenzene oxidation of lignin model compounds, spruce wood and spruce native lignin. J. Am. Chem. Soc. 77:2831-2833.

Pew, J.C. (1963) Evidence of a biphenyl group in lignin. J. Org. Chem. 28:1048-1054.

Ralph, J., Lundquist, K., Brunow, G., Lu, F., Kim, H., Schatz, P.F., Marita, J.M., Hatfield, R.D., Ralph, S.A., Christensen, J.H., Boerjan, W. (2004) Lignins: natural polymers from oxidative coupling of 4-hydroxyphenyl- propanoids. Phytochem. Rev. 3:29-60.

Ralph, J., Akiyama, T., Kim, H., Lu, F.C., Schatz, P.F., Marita, J.M., Ralph, S.A., Reddy, M.S.S., Chen, F., Dixon, R.A. (2006) Effects of coumarate 3-hydroxylase down-regulation on lignin structure. J. Biol. Chem. 281:8843-8853.

Reinhoudt, D.N., de Jong, F., van de Vondervoort, E.M. (1981) Crown ethers with converging neutral binding sites: synthesis and complexation with t-butylammonium hexafluorophosphate. Tetrahedron 37:1753-1762.

Saito, K., Fukushima, K. (2005) Distribution of lignin interunit bonds in the differentiating xylem of compression and normal woods of Pinus thunbergii. J. Wood Sci. 51:246-251.

Sarkanen, K.V., Ludwig, C.H. (1971) Definition and nomenclature. In: Lignins: Occurrence, Formation, Structure and Reactions. Eds. Sarkanen, K.V., Ludwig, C.H. Wiley-Interscience, New York, USA. pp. 1-18.

Stewart, J.J., Akiyama, T., Chapple, C., Ralph, J., Mansfield, S.D. (2009) The effects on lignin structure of overexpression of ferulate 5-hydroxylase in hybrid poplar. Plant Physiol. 150:621-635.

Swan, B. (1965) Isolation of acid-soluble lignin from the Klason lignin determination. Sven. Papperstidn 68:791-795.

Tamai, A., Goto, H., Akiyama, T., Matsumoto, Y. (2015) Revisiting alkaline nitrobenzene oxidation: quantitative evaluation of biphenyl structures in cedar wood lignin (Cryptomeria japonica) by a modified nitrobenzene oxidation method. Holzforschung 69:951-958.

Timell, T.E. (1983) Origin and evolution of compression wood. Holzforschung 37:1-10.

Timell, T.E. (1986) Chemical properties of compression wood. In: Compression Wood in Gymnosperms. Springer-Verlag, Berlin. vol. 1. pp. 289-408.

Wagner, A., Ralph, J., Akiyama, T., Flint, H., Phillips, L., Torr, K., Nanayakkara, B., Te Kiri, L. (2007) Exploring lignification in conifers by silencing hydroxycinnamoyl-CoA:shikimate hydroxycinnamoyltransferase in Pinus radiata. Proc. Natl. Acad. Sci. USA 104:11856-11861.

Weng, J.K., Akiyama, T., Bonawitz, N.D., Li, X., Ralph, J., Chapple, C. (2010) Convergent evolution of syringyl lignin biosynthesis via distinct pathways in the lycophyte Selaginella and flowering plants. Plant Cell 22:1033-1045.

Yamamoto, H., Okuyama, T., Yoshida, M., Sugiyama, K. (1991) Generation process of growth stresses in cell walls. III. Growth stress in compression wood. Mokuzai Gakkaishi 37:94-100.

Yamashita, S., Yoshida, M., Takayama, S., Okuyama, T. (2007) Stemrighting mechanism in gymnosperm trees deduced from limitations in compression wood development. Ann. Bot. 99:487-493.

Yeh, T.-F., Braun, J.L., Goldfarb, B., Chang, H.-M., Kadla, J.F. (2006) Morphological and chemical variations between juvenile wood, mature wood, and compression wood of loblolly pine (Pinus taeda L.). Holzforschung 60:1-8. 